\title{
ANIMAL MODELS OF DISEASE
}

\section{Feline hyperthyroidism: an animal model for toxic nodular goiter}

\author{
Mark E Peterson ${ }^{1,2}$ \\ ${ }^{1}$ Animal Endocrine Clinic, 21 West 100th Street, New York, New York 10025, USA \\ ${ }^{2}$ Department of Clinical Sciences, New York State College of Veterinary Medicine, Cornell University, \\ Ithaca, New York 14853, USA
}

Correspondence should be addressed to M E Peterson

Email

drpeterson@

animalendocrine.com

\begin{abstract}
Since first discovered just 35 years ago, the incidence of spontaneous feline hyperthyroidism has increased dramatically to the extent that it is now one of the most common disorders seen in middle-aged to senior domestic cats. Hyperthyroid cat goiters contain single or multiple autonomously (i.e. TSH-independent) functioning and growing thyroid nodules. Thus, hyperthyroidism in cats is clinically and histologically similar to toxic nodular goiter in humans. The disease in cats is mechanistically different from Graves' disease, because neither the hyperfunction nor growth of these nodules depends on extrathyroidal circulating stimulators. The basic lesion appears to be an excessive intrinsic growth capacity of some thyroid cells, but iodine deficiency, other nutritional goitrogens, or environmental disruptors may play a role in the disease pathogenesis. Clinical features of feline toxic nodular goiter include one or more palpable thyroid nodules, together with signs of hyperthyroidism (e.g. weight loss despite an increased appetite). Diagnosis of feline hyperthyroidism is confirmed by finding the increased serum concentrations of thyroxine and triiodothyronine, undetectable serum TSH concentrations, or increased thyroid uptake of radioiodine. Thyroid scintigraphy demonstrates a heterogeneous pattern of increased radionuclide uptake, most commonly into both thyroid lobes. Treatment options for toxic nodular goiter in cats are similar to that used in humans and include surgical thyroidectomy, radioiodine, and antithyroid drugs. Most authorities agree that ablative therapy with radioiodine is the treatment of choice for most cats with toxic nodular goiter, because the animals are older, and the disease will never go into remission.
\end{abstract}

\author{
Key Words \\ - hyperthyroidism \\ - thyrotoxicosis \\ - thyroid \\ - cat \\ - Plummer's disease
}

\section{Introduction}

Spontaneous hyperthyroidism is an extremely common endocrine disorder of middle- to old-aged cats (Mooney \& Peterson 2012, Peterson 2013a). Since first being reported in the USA in the late 1970s (Peterson et al. 1979), there has been a dramatic increase in the prevalence of hyperthyroidism in cats, and it has emerged worldwide as one of the most common diseases affecting mature and senior cats (Peterson 2012).

The domestic cat is the only nonhuman species in which spontaneous thyrotoxicosis develops frequently enough to allow a system investigation into its pathogenesis. Because feline hyperthyroidism most often results

Published by Bioscientifica Ltd

This paper forms part of a thematic review series on Animal Models of Disease. The Guest Editor for this section was Alan Conley University of California at/Davis oDavis, : $39: 52 \mathrm{PM}$ CA, USA. 
from benign adenomatous nodules of the thyroid gland, it is both clinically and pathologically similar to toxic nodular goiter or Plummer's disease in humans (Hoenig et al. 1982, Carpenter et al. 1987, Gerber et al. 1994, Paschke 2013). Similar to human toxic nodular goiter, this feline disease is a progressive disease, with cats transitioning from a subclinical stage to overt hyperthyroidism as the automatous thyroid nodules increase in size (Wakeling et al. 2007, 2011, Broome \& Peterson 2014, Peterson \& Broome 2014a). As such, this disease offers a unique animal model for the study of toxic nodular goiter, as well as other disorders associated with benign neogeneration of endocrine tissue ranging from simple hyperplasia and adenomatous hyperplasia to true adenoma (Gerber et al. 1994, Derwahl \& Studer 2002).

This review examines the etiopathology of spontaneous toxic nodular goiter in cats in the context of the corresponding human disease. In addition, the epidemiology, clinical features, laboratory diagnosis, scintigraphic features, and treatment for this feline thyroid disease have been reviewed, again comparing the disease with toxic nodular goiter of man.

\section{Studies characterizing feline hyperthyroidism as a toxic nodular goiter}

\section{Pathology of feline toxic nodular goiter}

Pathologically, hyperthyroidism in cats is most similar to the human toxic nodular goiter (i.e. Plummer's disease; Gerber et al. 1994, Khan \& Nose 2010). Histopathological examination of tissues reveal that the thyroid glands of cats with hyperthyroidism contain single or multiple hyperplastic or adenomatous nodules ranging in size from $<1 \mathrm{~mm}$ to $3 \mathrm{~cm}$ diameter (Hoenig et al. 1982, Carpenter et al. 1987, Peter et al. 1987; Fig. 1). The sizes of the cells, as well as the volume of the nuclei, are invariably much larger within the nodules than in the surrounding, normal paranodular tissue. These cells characteristically show little nuclear atypia or mitotic activity.

The follicles comprising the hyperplastic or adenomatous nodules are lined by a columnar to cuboidal epithelium and contain only faintly periodic acid Schiff (PAS)-stained colloid (Figs 1 and 2). As PAS avidly stains thyroglobulin in the colloid, the faint staining observed in these feline toxic nodules is due to decreased storage of thyroglobulin resulting from the hypersecretory state (Carpenter et al. 1987). Follicular size varies considerably between different nodules; from an almost solid growth pattern in some nodules to a macrofollicular architecture

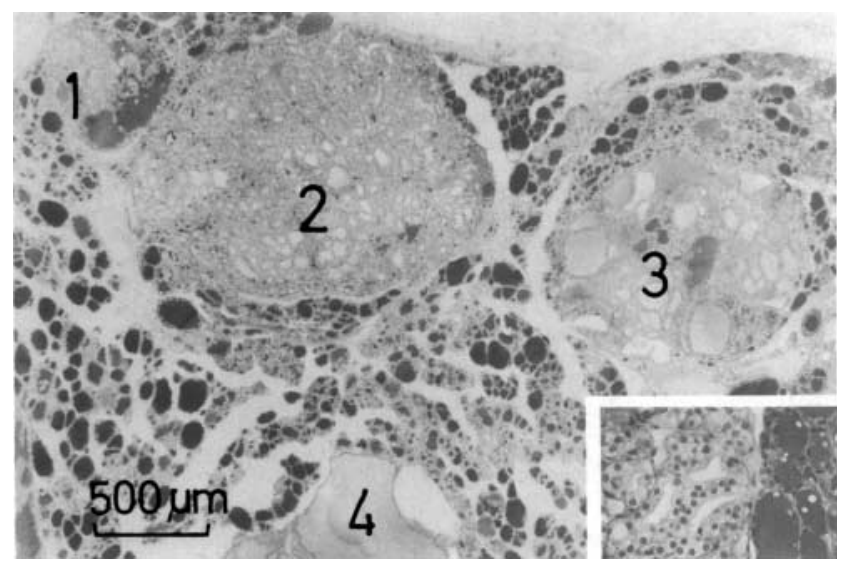

\section{Figure 1}

Histologic section across a nodular goiter of a hyperthyroid cat stained with periodic acid-Schiff (PAS). This stain was used to highlight glycoprotein content (thyroglobulin) within the colloid as well as follicular structure. Four nodules (1, 2, 3 and 4) consisting of follicles lined by cuboidal epithelial cells with large nuclei (see inset) and filled with pale, barely stained colloid are shown. Some areas within the nodules are almost solid structures with only tiny follicular lumina. Other nodules may contain some large follicles separated by densely cellular parenchyma (3). Occasionally, even a giant follicle may form within the nodules (4). Adapted, with permission, from Peter HJ, Gerber H, Studer H, Becker DV \& Peterson ME 1987 Autonomy of growth and of iodine metabolism in hyperthyroid feline goiters transplanted onto nude mice. Journal of Clinical Investigation 80 491-498 (Copyright American Society for Clinical Investigation).

in others. The feline extranodular tissue is generally built up by colloid-rich follicles, which are lined by a flat epithelium (Fig. 2). The histologic appearance of this paranodular tissue resembles that of thyroid glands obtained from animals treated with levothyroxine ( $\mathrm{L}-\mathrm{T}_{4}$ ) and reflects the fact that circulating thyroid-stimulating hormone (TSH) is suppressed in these cats as a result of their chronic hyperthyroid state (Gerber et al. 1985, Capen 2001, Peterson 2013b).

The pathologic changes in the thyroid glands of cats with toxic nodular goiter are almost always benign (Hoenig et al. 1982, Carpenter et al. 1987, Peter et al. 1987, Wakeling et al. 2007). Approximately, 2\% of hyperthyroid cats develop thyroid carcinoma, which can be classified as either follicular, papillary or mixed (Turrel et al. 1988, Hibbert et al. 2009). However, the prevalence of malignancy developing within a feline goiter appears to increase progressively over time, especially if the toxic goiter is not definitively treated with thyroidectomy or radioiodine (Peterson 2012, Broome \& Peterson 2014, Peterson \& Broome 2014a). A similar prevalence of thyroid cancer is also reported in humans with toxic nodular goiter (Sokal 1954, Gandolfi et al. 2004, Cerci et al. 2007, Khan \& Nose 2010). In both man and cats, the thyroid

Published by Bioscientifica Ltd 


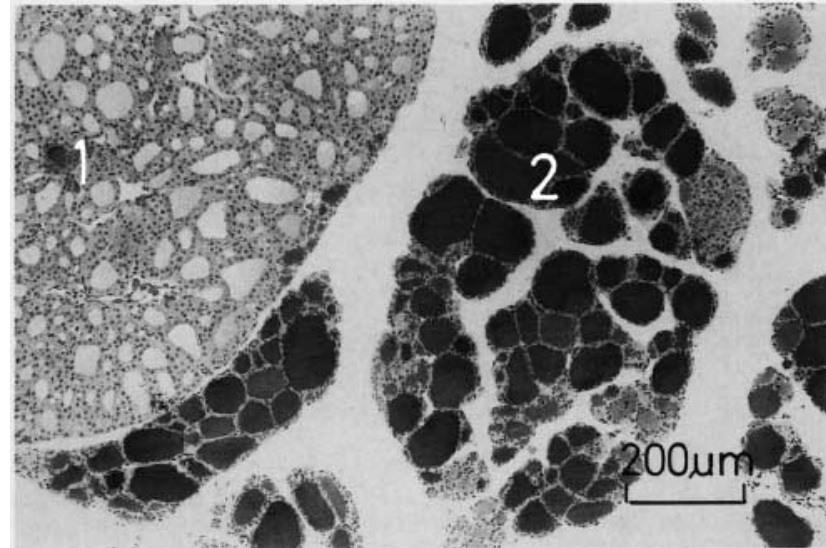

Figure 2

Histologic section of a hyperthyroid cat goiter obtained at surgery stained with periodic acid-Schiff (PAS). Note areas of hyperplastic nodular tissue with follicles lined by cuboidal or columnar epithelial cells (1) and areas of paranodular tissue with follicles filled with strongly PAS-positive colloid and lined by flat or cuboidal epithelial cells (2). Reproduced, with permission, from Peter HJ, Gerber H, Studer H, Peterson ME, Becker DV \& Groscurth P 1991 Autonomous growth and function of cultured thyroid follicles from cats with spontaneous hyperthyroidism. Thyroid 1 331-338 (Copyright Mary Ann Liebert Inc).

cancer associated with long-standing toxic nodular goiter tends to have low metastasis potential.

\section{Autoradiography studies of feline toxic nodular goiter}

Autoradiographs obtained from the goiter tissue of hyperthyroid cats injected with ${ }^{125}$ I before surgery show that their hyperplastic or adenomatous nodules take up and incorporate radioiodine intensely (Peter et al. 1987; Fig. 3). Very little ${ }^{125} \mathrm{I}$ is taken up by the paranodular tissue, which reflects the fact that the circulating TSH concentration is suppressed in these cats as a result of their chronic hyperthyroid state (Peterson 2013b). Within the nodules, radioiodine incorporation may not be increased in all individual follicles but varies from nil to very intense. This resembles the marked interfollicular heterogeneity of iodine metabolism reported in the thyroid of patients with multinodular goiter (Miller \& Kawas 1966, Peter et al. 1985, Studer et al. 1989).

Marked heterogeneity of radioiodine incorporation is also seen in the thyroid tissue of normal cats (Peter et al. 1987). When evaluated $<4 \mathrm{~h}$ after ${ }^{125} \mathrm{I}$ administration, that is, before the newly iodinated thyroglobulin molecules could move away form the colloid-thyrocyte border and mix with the rest of the colloid (Gerber et al. 1985), clear-cut differences in the amount of radioiodine metabolism can be observed, even among the cells of individual follicles (Peter et al. 1987). In this aspect, the feline thyroid gland does not differ from other species, including man (Studer et al. 1989).

\section{Xenotransplantation studies with feline toxic nodular goiter}

The autonomy of feline toxic goiter tissue has been studied by transplanting thyroid tumor tissue collected from the hyperthyroid cats at surgery into athymic nude mice (Gerber et al. 1996). In these studies, we evaluated the proliferation and iodine incorporation of transplanted normal cat thyroid tissue, as well as feline toxic goiter tissue, by injecting the mice with either ${ }^{125} \mathrm{I}$ or ${ }^{131} \mathrm{I}$ and tritium-thymidine respectively (see below). The mice were treated with either $\mathrm{L}_{-} \mathrm{T}_{4}$ to suppress circulating TSH or methimazole to raise TSH concentrations as needed (Peter et al. 1985, 1987).

When toxic nodular goiter tissue from normal or hyperthyroid cats was transplanted into dysthymic nude mice, the feline thyroid tissue continued to grow in its original nodular histologic pattern within the new host (Peter et al. 1987). These transplantation studies of feline hyperthyroid tissue into nude mice are similar to the results reported after transplantation of adenomatous thyroid tissue from human patients with toxic nodular goiter into nude mice (Peter et al. 1985).

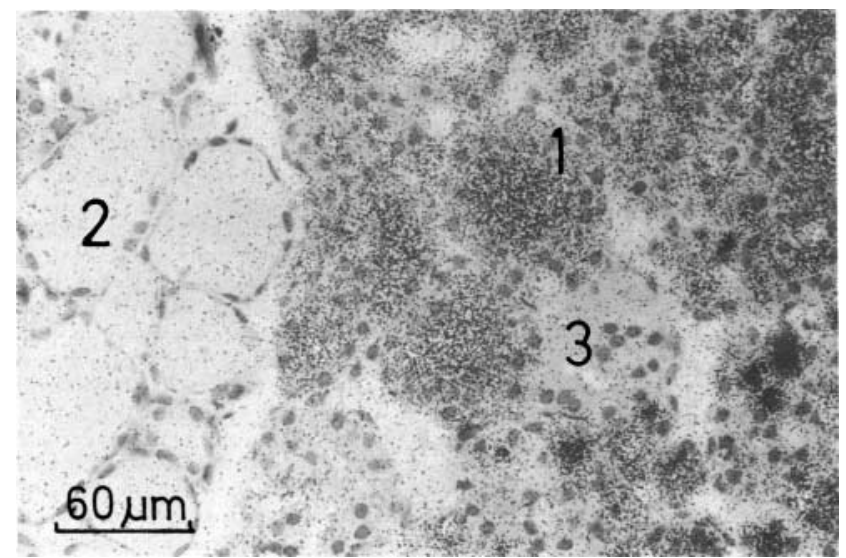

\section{Figure 3}

Autoradiograph of hyperthyroid cat goiter labeled with $20 \mu \mathrm{Ci}$ of ${ }^{125} \mathrm{I}$ for $4 \mathrm{~h}$ before surgery, with nodular tissue then counter-stained with nuclear fast red stain. Note intense iodine organification within a hyperplastic nodule (1) and very little iodine uptake within the adjacent paranodular tissue (2). In some hyperplastic nodules, there was considerable heterogeneity of radioiodine organification among individual follicles, even within the same nodule (3). Exposure time 65 days. Reproduced, with permission, from Peter HJ, Gerber H, Studer H, Becker DV \& Peterson ME 1987 Autonomy of growth and of iodine metabolism in hyperthyroid feline goiters transplanted onto nude mice. Journal of Clinical Investigation $\mathbf{8 0}$ 491-498 (Copyright American Society for Clinical Investigation).

Published by Bioscientifica Ltd 
lodine metabolism, as evaluated by incorporation of radioiodine To study the function and iodine metabolism of cat thyroid tissue, we investigated the radioiodine uptake into the transplanted feline normal and toxic goiter tissue, which had been growing in the $\mathrm{T}_{4}$-treated host mice. In the normal cat thyroid tissue, ${ }^{131}$ I uptake was low in the absence of TSH and did not increase after administration of hyperthyroid cat serum, but the ${ }^{131} \mathrm{I}$ uptake of the normal tissue did increase two- to fourfold after administration of bovine TSH (Peter et al. 1987). In contrast to the normal transplanted thyroid tissue, the uptake and organification of radioiodine was very intense in the transplanted feline goiter tissue (Fig. 4). As with the normal thyroid tissue, however, administration of serum from the hyperthyroid donor cat failed to increase the iodine uptake (Peter et al. 1987; Fig. 4).

Overall, these findings indicate that, regardless of the initiating cause of the cats' hyperthyroidism, the xenotransplanted toxic goiter tissue continues to function in

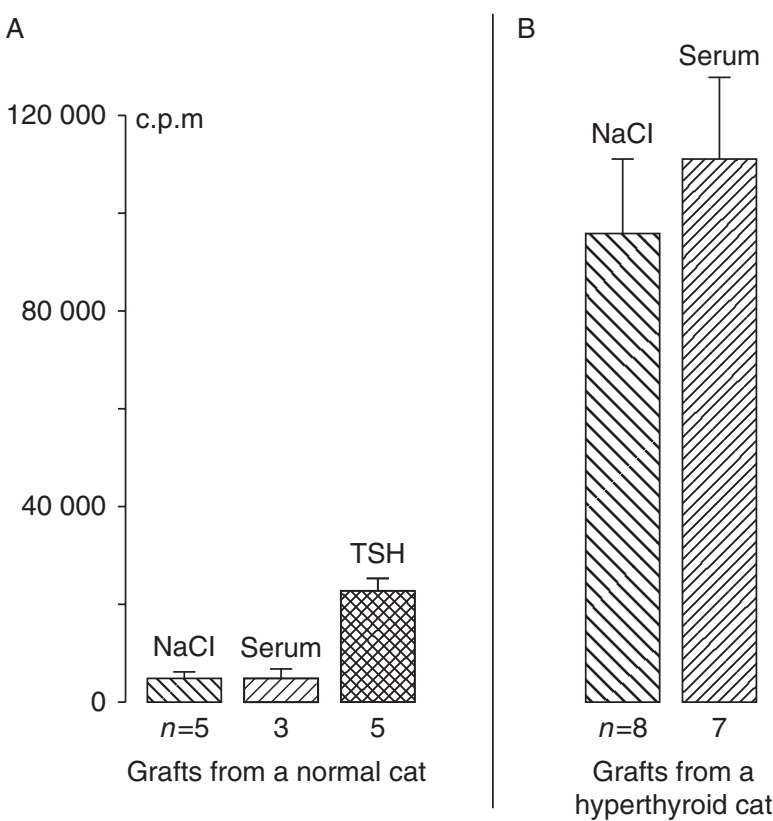

\section{Figure 4}

Radioiodine uptake into xenotransplanted normal (A) and toxic goiter tissue (B) growing in $\mathrm{T}_{4}$-treated host mice labeled with $20 \mu \mathrm{Ci}$ of ${ }^{131} \mathrm{I}$ for $3 \mathrm{~h}$ before being killed. ${ }^{131} \mathrm{I}$ uptake of mean ( \pm S.E.M.) counts per minute (c.p.m.) into normal tissues (saline control, $\mathrm{NaCl}, n=5$ ) is low in the absence of TSH and is not enhanced by administration of hyperthyroid cat serum (serum, $n=3)$, but ${ }^{131}$ I uptake is readily stimulated by TSH (TSH, $\left.n=5\right)(\mathrm{A})$. Toxic goiter tissue shows unabated high autonomous iodine uptake $(\mathrm{NaCl}$, $n=8$ ) that is not significantly altered by administration of serum from the hyperthyroid donor cat (serum, $n=7$ ) (B). Reproduced, with permission, from Peter HJ, Gerber H, Studer H, Becker DV \& Peterson ME 1987 Autonomy of growth and of iodine metabolism in hyperthyroid feline goiters transplanted onto nude mice. Journal of Clinical Investigation $\mathbf{8 0}$ 491-498 (Copyright American Society for Clinical Investigation). Printed in Great Britain
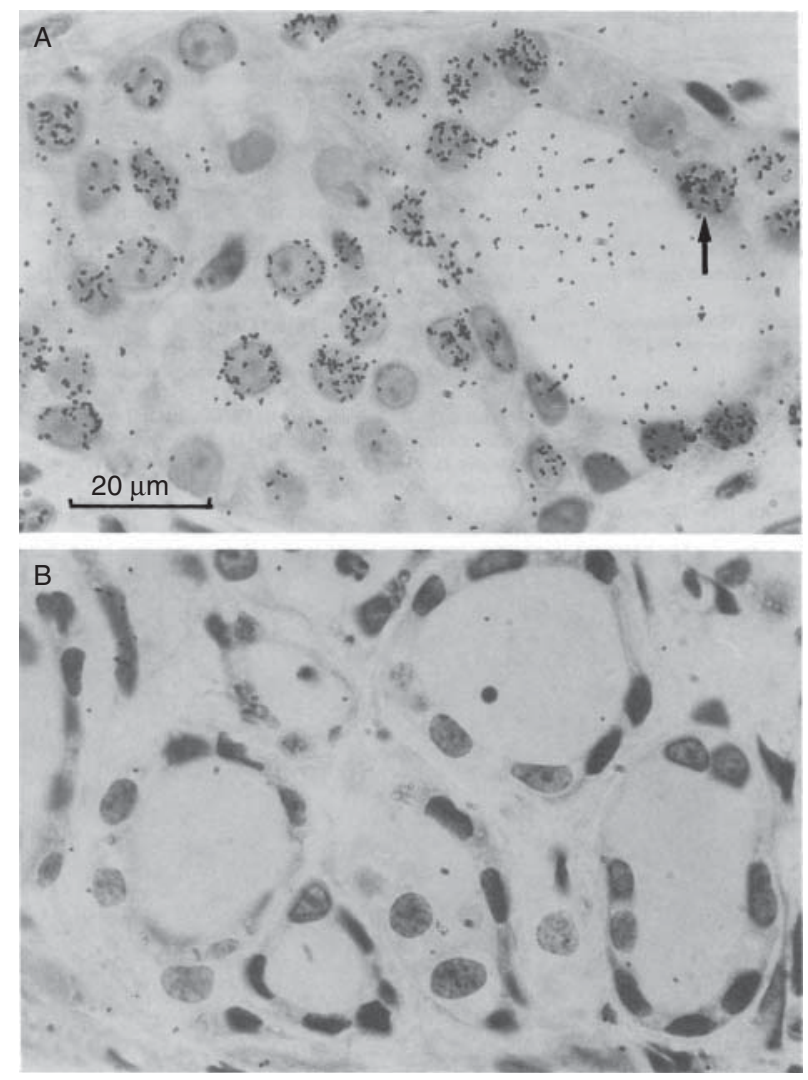

\section{Figure 5}

Histological sections of a xenograft of a toxic goiter of a geriatric cat grown in a $\mathrm{T}_{4}$-treated host mice labeled with $\left[{ }^{3} \mathrm{H}\right]$ thymidine 3 months before being killed, then counter-stained with nuclear fast red. Autoradiograph $A$, taken from a hyperplastic area and exposed 3 months after radioiodine labeling, shows that despite the absence of TSH, a considerable fraction of the follicular cells has incorporated the thymidine label into their nuclei (arrow). The grains within the follicular lumina result from residual ${ }^{131}$ I activity. No incorporation of $\left[^{3} \mathrm{H}\right]$ thymidine into follicular cell nuclei is found in autoradiograph B showing a paranodular area, exposed under identical conditions (72 days). Reproduced, with permission, from Peter $\mathrm{HJ}$, Gerber H, Studer H, Becker DV \& Peterson ME 1987 Autonomy of growth and of iodine metabolism in hyperthyroid feline goiters transplanted onto nude mice. Journal of Clinical Investigation 80 491-498 (Copyright American Society for Clinical Investigation).

the host mouse and is independent from circulating stimulatory factors (e.g. thyroid-stimulating immunoglobulins (TSIs)).

\section{Proliferation, as evaluated by incorporation of tritium-} thymidine In this study, we used autoradiography to assess follicular cell proliferation in the transplanted feline toxic goiter tissue (Peter et al. 1987). Despite the fact that $\mathrm{TSH}$ was suppressed in the $\mathrm{T}_{4}$-treated nude mice, a considerable fraction of the autonomously proliferating feline follicular cells incorporated the thymidine label into their nuclei. In contrast, no incorporation of the

Published by Bioscientifica Ltd 
${ }^{3} \mathrm{H}$-thymidine label was found within the suppressed paranodular thyroid tissue (Fig. 5).

These findings indicate that the xenotransplanted toxic goiter tissue continues to grow in the host mouse and, thus, is independent from circulating stimulatory factors. Again, these are similar to the results reported after transplantation of thyroid tissue from human patients with toxic nodular goiter (Peter et al. 1985).

\section{Studies using primary cultures of follicles and thyrocytes from toxic adenomatous cat thyroids}

Consistent with these xenotransplantation studies, adenomatous thyroid cells from hyperthyroid cats cultured in TSH-free media also continue to grow and function autonomously (Peter et al. 1991). In those studies, primary cultures of enzymatically dissociated follicles from 15 hyperthyroid cat goiters and from three normal cat thyroid glands were embedded in collagen gels to preserve their 3D structure. Growth and function in chemically defined media were assessed by autoradiography after double labeling with ${ }^{3} \mathrm{H}$-thymidine and ${ }^{131} \mathrm{I}$-Na. Iodine organification in the follicles from normal glands was TSH-dependent, but intense radioiodine organification occurred in the follicles from hyperfunctioning goiters even in the absence of TSH (Fig. 6). Similarly, twice as many follicular cells of hyperfunctioning thyroid tissue, maintained without TSH in the medium, were labeled after exposure to ${ }^{3} \mathrm{H}$-thymidine than in follicles from normal glands (Peter et al. 1991; Fig. 7).

The results of these feline cell culture studies are in line with the xenotransplantation studies and suggest that intrinsic alterations of thyroid cell function lead to the autonomy of follicular growth and function that characterizes hyperthyroidism in the domestic cat. Again, extrathyroidal-stimulating factors are not involved in the pathogenesis of feline nodular goiter.

In other studies, isolated thyroid follicular cells from normal and hyperthyroid cats were enzymatically digested and grown in a monolayer cell culture to evaluate both thyroglobulin production and DNA synthesis (Gerber et al. 1994, Ward et al. 2005a). TSH stimulated mitogenesis and thyroglobulin expression in both normal and hyperthyroid cells, but a higher concentration of TSH was needed to maximally stimulate both activities in the hyperthyroid cells (Ward et al. 2005a). Other studies of monolayer hyperthyroid cell culture, however, found no effect of TSH on ${ }^{3} \mathrm{H}$-thymidine uptake in hyperthyroid cells (Gerber et al. 1991), illustrating that cells from different feline goiters may show a high degree of heterogeneity in culture. Overall, these data reinforce the idea that feline toxic nodular goiter cells have a high level of basal, unstimulated activity with dysregulated growth and hormone synthesis, as would be expected in autonomous cells (Gerber et al. 1994, Ward et al. 2005a).

\section{Mutations of the TSH receptor and G-protein alpha subunit $\mathrm{G} \alpha_{s}$ (GNAS)}

Mutations in the thyrotropin receptor gene, leading to constitutive activation of the TSH receptor (TSHR), are common in human patients with both toxic nodular goiter and toxic adenoma. Less commonly, constitutively activating mutations in the adenylate cyclase stimulation

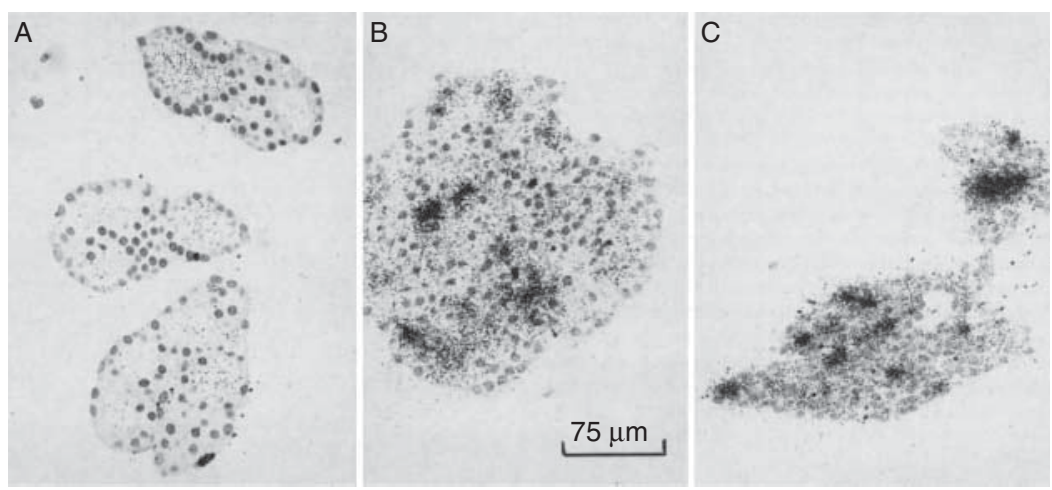

\section{Figure 6}

Autoradiograph showing radioiodine organification in follicles embedded in collagen gel, counter-stained with nuclear fast red. In normal follicles cultured without TSH, the density of silver grains within the lumina is low (A), whereas intense ${ }^{131}$ I organification occurs in the presence of TSH (B). In contrast, follicles from hyperthyroid goiter tissue intensely accumulate the iodine label despite the absence of TSH (C). All cultures were labeled under identical conditions, and slides were exposed for 5 days. Reproduced, with permission, from Peter $\mathrm{HJ}$, Gerber $\mathrm{H}$, Studer $\mathrm{H}$, Peterson ME, Becker DV \& Groscurth P 1991 Autonomous growth and function of cultured thyroid follicles from cats with spontaneous hyperthyroidism. Thyroid 1 331-338 (Copyright Mary Ann Liebert Inc). http://joe.endocrinology-journals.org DOI: 10.1530/JOE-14-0461
C 2014 Society for Endocrinology Printed in Great Britain
Published by Bioscientifica Ltd 

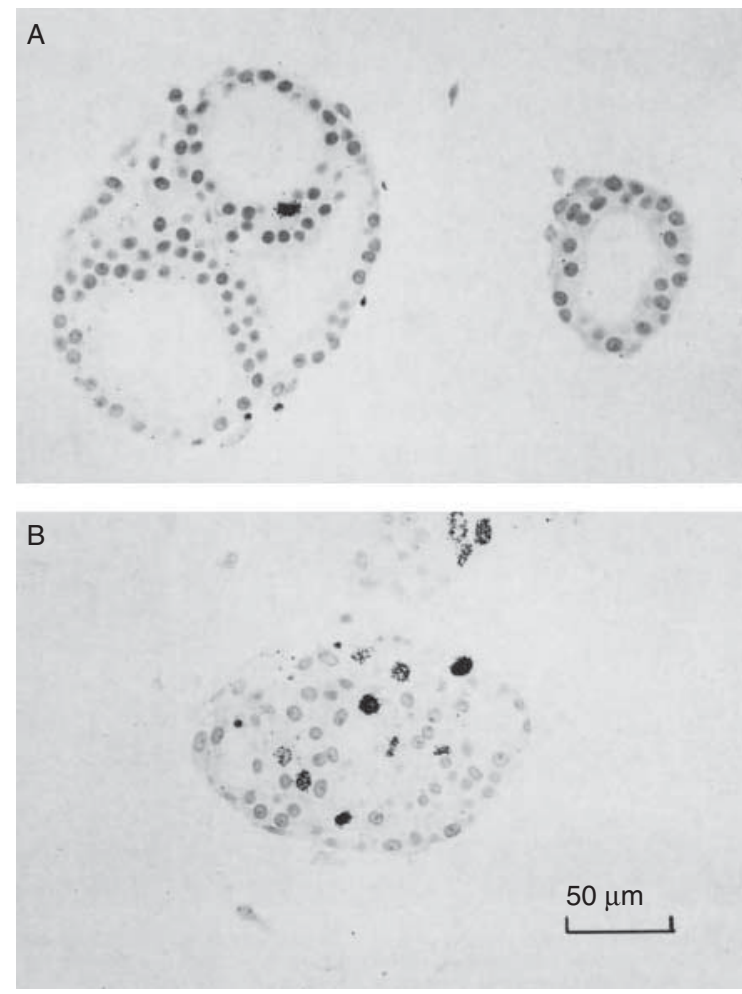

\section{Figure 7}

Autoradiograph of a histological section counter-stained with nuclear fast red showing follicular cell proliferation in follicles from normal and hyperfunctioning thyroid tissue cultured in the absence of TSH. In normal follicles (A), only an occasional cell has incorporated the thymidine label. In contrast, some clusters of follicles contain up to $12 \%{ }^{3} \mathrm{H}$-thymidine-labeled cells in cultures from hyperthyroid goiters (B). Reproduced, with permission, from Peter HJ, Gerber H, Studer H, Peterson ME, Becker DV \& Groscurth P 1991 Autonomous growth and function of cultured thyroid follicles from cats with spontaneous hyperthyroidism. Thyroid 1 331-338 (Copyright Mary Ann Liebert Inc).

protein $\mathrm{G} \alpha_{\mathrm{s}}$ subunit (GNAS) are found (Krohn \& Paschke 2002, Krohn et al. 2005, Liu et al. 2010). As a consequence of these mutations, chronic activation of the adenylatecyclase-cAMP cascade takes place, leading to enhanced iodine uptake by the thyroid, increased thyroid hormone synthesis and release, and clinical hyperthyroidism (Kopp 2001, Krohn et al. 2005).

In hyperthyroid cats, early studies carried out in small numbers of cats failed to identify any TSHR mutations (Pearce et al. 1997, Peeters et al. 2002). However, a later detailed study of 134 nodules from 50 hyperthyroid cats found ten missense mutations, of which five have previously been associated with human hyperthyroidism (Watson et al. 2005). The most common TSHR mutation detected in cats is Met452-Thr (a substitution of methionine by threonine), which is analogous to the human mutation Met453-Thr observed in sporadic human nodular goiter (Parma et al. 1997, Nishihara et al. 2009). In addition, GNAS mutations have also been documented in four of ten hyperthyroid cats examined (Peeters et al. 2002). None of these identified mutations are present in thyroid tissue of normal cats.

Not all nodules taken from an individual cat or thyroid lobe showed the same mutations, with different mutations appearing in different adenomas and hyperplastic nodules (Watson et al. 2005). A similar scenario has been found in human hyperthyroidism (Fuhrer et al. 1996, Duprez et al. 1997, Holzapfel et al. 1997, Tonacchera et al. 1998). Similar to human patients, the finding of mutations in the TSHR gene or the GNAS gene in hyperthyroid cats suggests that such mutations play a role in the pathogenesis of feline toxic nodular goiter in some, but not all, cases.

\section{Abnormalities in thyroid growth and signaling in feline toxic nodular goiter}

In the normal thyroid cell, growth and function are controlled by the interaction of TSH with its G-proteincoupled receptor on the surface of the thyroid cell (Dumont et al. 1992, Kleinau et al. 2013). Heterotrimeric $G$ proteins of the $G \alpha_{s}$ and $G \alpha_{i}$ subgroups regulate adenylyl cyclase activity, which in turn controls the formation of cAMP (Wettschureck \& Offermanns 2005). The $G_{s}$ proteins are stimulatory to adenylyl cyclase, while the $G_{i}$ proteins are inhibitory. Adenylyl cyclase activity and cAMP formation result from cumulative expression and activity of both the $G_{s}$ and $G_{i}$ proteins.

Abnormalities of any element of the TSHR-G proteincAMP regulatory pathway can result in the uncontrolled cellular proliferation and excess hormone secretion seen in hyperthyroid disease (Kopp 2001, Krohn et al. 2005). As noted earlier, mutations in the TSHR gene and the alpha subunit of the $G_{s}$ protein have been documented in both human and feline toxic nodular goiter. These findings suggest that these gene mutations play a role in the disease; however, the finding of such a gene mutation does not always equate to a functional defect leading to hyperthyroidism (Derwahl et al. 1996, Fuhrer et al. 1996, Watson et al. 2005).

For instance, increased expression of alpha subunits of both $G_{s}$ and $G_{i}$ has been demonstrated in human adenomatous thyroid tissue (Siperstein et al. 1991, Delemer et al. 1992), and one subset of $G \alpha_{i}$ proteins, $\mathrm{G} \alpha_{\mathrm{i} 1}$, has been shown to be selectively expressed in some thyroid nodules (Selzer et al. 1993). Still, marked variation in G-protein coupling and signal transduction has been reported, as supported by the variable $G \alpha_{s}$ or $G \alpha_{i}$ protein

Published by Bioscientifica Ltd 
expression in hyperfunctioning thyroid nodules (Selzer et al. 1993, Derwahl et al. 1996, Holzapfel et al. 2002). The relationship between $\mathrm{G}_{\mathrm{s}}$ expression, the cAMP cascade, and the subsequent mitogenic response to this signaling pathway (eventually leading to thyroid nodular hyperplasia or adenoma) is complex. Therefore, correlating the expression of one protein with the overall activity of the cAMP cascade can be misleading (Uytterspot et al. 1995, Holzapfel et al. 2002).

In cats with toxic nodular goiter, two reports have also demonstrated that tissue from five hyperthyroid cats had a reduced quantity of $\mathrm{G} \alpha_{\mathrm{i}}$ proteins (in particular, $\mathrm{G} \alpha_{\mathrm{i} 2}$ ), but no difference was detected in the amounts of $\mathrm{G} \alpha_{\mathrm{s}}$ between hyperthyroid and control cats (Hammer et al. 2000, Ward et al. 2005b). These results suggest that decreased amounts of $\mathrm{G} \alpha_{\mathrm{i}}$ may remove the negative inhibition of adenylyl cyclase and result in increased cAMP formation, which could contribute to the nodular growth in some hyperthyroid cats (Hammer et al. 2000, Ward et al. $2005 b$, 2010). In both of these studies, only five hyperthyroid cats were used, and unfortunately, we do not know whether any of the cats had activating mutations of either the TSHR or GNAS.

\section{Thyroid autoimmunity and circulating thyroid stimulators in feline toxic nodular goiter}

Initial theories regarding the pathogenesis of feline hyperthyroidism revolved around it being similar to Graves' disease, an autoimmune disorder in which circulating stimulatory autoantibodies activate the TSHR leading to thyroid hyperplasia and unregulated thyroid hormone production and secretion (Schott et al. 2005, Menconi et al. 2014). As these TSIs stimulate growth of all thyrocytes, diffuse hyperplasia of the both thyroid lobes is a characteristic feature of Graves' disease.

In support of an autoimmune pathogenesis, early studies carried out in hyperthyroid cats suggested that circulating thyroid autoantibodies (i.e. thyroid microsomal and antinuclear) were not uncommon, being present in one-third of cats examined (Kennedy \& Thoday 1988). However, subsequent studies by these same investigators failed to identify any evidence for circulating levels of TSIs (specific autoantibody characteristic of Graves' disease) in hyperthyroid cats, a finding confirmed by others (Peterson et al. 1987, Kennedy \& Thoday 1989). These studies used a bioassay method (the Fischer rat thyroid cell line, FTRL5), in which cAMP production is used to indicate serum antibody action. No significant difference was detected in intracellular cAMP concentrations in FTRL5 cells incubated with the IgG extracted from normal vs hyperthyroid cat serum (Peterson et al. 1987, Kennedy \& Thoday 1989). In the most recent and definitive study, the feline TSHR was cloned, and activation by whole and purified IgG fractions of hyperthyroid cat sera was investigated in a sensitive expression system (Nguyen et al. 2002). Serum and IgG fractions of serum from the 16 hyperthyroid cats did not stimulate cAMP production in human embryonic kidney cells (TSA-201) transfected with feline TSHRs, whereas serum and IgG fractions from patients with Graves' hyperthyroidism did stimulate cAMP production (Nguyen et al. 2002). Overall, these results indicate that feline hyperthyroidism does not result from high circulating concentration of TSIs and, in that respect, is not analogous to Graves' disease.

Although cats with toxic nodular goiter do not have circulating TSIs, high titers of serum thyroid growthstimulating immunoglobulins (TGIs) have been measured in hyperthyroid cats (Brown et al. 1992). These autoantibodies, which act to promote thyroid growth but not to stimulate thyroid hormone secretion, also have been reported in human patients with toxic nodular goiter, as well as in patients with Graves' disease, Hashimoto's thyroiditis, and euthyroid goiter (Brown 1995). Despite the presence of these autoantibodies, their clinical significance in human patients remains unclear. Similarly, in cats, there is no correlation between thyroid function and TGI activity in vitro, and their role in the pathogenesis of hyperthyroidism remains unclear. Some have questioned whether circulating TGIs even exist (Zakarija \& McKenzie 1990) and, in any case, TGIs have largely been forgotten over the last two decades. Our xenotransplantation and thyroid culture studies (see above) clearly show that in vivo growth and hyperfunction of cat toxic goiters no longer depends on circulating extra-thyroidal stimulators (Peter et al. 1987), and the basic lesion associated with feline nodular goiter appears to be an excessive intrinsic growth potential of some thyroid cell subsets, similar to that observed in human toxic nodular goiter (Peter et al. 1985, Studer et al. 1989). Of course, a very weak stimulator of thyroid growth (such as circulating TGIs) that enhances the initial transformation of a normal thyroid gland into a nodular goiter certainly remains a possibility.

Overall, all of these studies provide evidence against the presence of circulating thyroid-stimulating factors as a mechanism underlying the pathogenesis of feline toxic goiter. In contrast, these studies support a model involving an intrinsic autonomy of thyroid follicular cell growth and function similar to that seen in human toxic nodular goiter (Peter et al. 1985, Studer et al. 1989).

Published by Bioscientifica Ltd 


\section{Epidemiology of feline toxic nodular goiter: a common worldwide disorder of older domestic cats}

Feline thyroid nodular disease and hyperthyroidism appears to be a relatively new disorder of cats, first described in 1979 (Peterson et al. 1979). Before that time, goiter had been found at necropsy in a few cats, and nodules were observed histopathologically, but these abnormalities were relatively rare and were not associated with the clinical signs related with hyperthyroidism (Lucke 1964, Leav et al. 1976).

Over the last 35 years, the prevalence of thyroidal pathologic abnormalities and the associated state of hyperthyroidism have steadily increased. It is now accepted as the most common endocrine disorder in cats and the most important cause of morbidity in middle-aged cats in the USA, Canada, UK, Europe, Australia, New Zealand, and Japan (Mooney \& Peterson 2012, Peterson 2012).

The prevalence of feline hyperthyroidism (toxic nodular goiter) in my clinics has been reported to reach $10 \%$ of all cats older than 10 years (Peterson M E, 2014, unpublished observations), which is equivalent to a human age of over 60 years (Vogt et al. 2010), and the prevalence appears to increase ever further with advancing age. Similar prevalence rates have been reported in other parts of the world over the last decade, ranging from 7.4\% in London (Wakeling et al. 2011) to $8.9 \%$ in Japan (Miyamoto et al. 2002), 11.4\% in Germany (Sassnau 2006), and $20.1 \%$ in the most recent study in Warsaw (Gójska-Zygner et al. 2014). In contrast to these high feline prevalence rates, the prevalence of toxic nodular goiter in older human patients is much less, ranging between 0.4 and $2.0 \%$ (Vanderpump 2011), although a higher prevalence rate is seen in iodine-deficient areas (Aghini-Lombardi et al. 1999).

To put these prevalence rates into perspective, 25\% of domestic cats living in the USA and Canada are older that 10 years of age (Perrin 2009, American Veterinary Medical Association 2012). The estimated population of cats in the USA and Canada is 80 million, which calculates out to be about 20 million geriatric cats. If $10 \%$ of these are hyperthyroid, that means that we have 2 million cats in the USA and Canada alone suffering from overt toxic nodular goiter. Again, this is an extremely common disease in older cats.

As in human patients, thyroid nodules, nontoxic goiter, and subclinical hyperthyroidism are also very common in elderly cats. In three studies in which senior euthyroid cats were screened for thyroid nodules, 38\%
(Chaitman et al. 1999), 59\% (Norsworthy et al. 2002a), and $76 \%$ (Boretti et al. 2009) of these cats had a palpable goiter. When these euthyroid nodules were examined histopathologically, $65-85 \%$ were confirmed as nodular hyperplasia or adenoma (Norsworthy et al. 2002b, Ferguson \& Freeman 2006). Similarly, in a postmortem study carried out in geriatric German cats (aged 13-16 years old, which is equivalent to $68-80$ human years), $76 \%$ had nodular goiter on histopathologic examination (Reese et al. 2002); again, this rate is much higher than that of overt hyperthyroidism (11.4\%) confirmed at the same institution (Sassnau 2006). Therefore, it has been demonstrated that histopathological thyroid changes consistent with nontoxic or toxic nodular goiter develop very frequently in older euthyroid cats.

Some euthyroid cats with palpable goiter will develop overt hyperthyroidism months to years later, as a result of continued growth of the thyroid nodule(s) (Ferguson \& Freeman 2006, Wakeling et al. 2007, 2011). As in human patients with toxic nodular goiter, cats likely undergo a phase of subclinical hyperthyroidism - defined as a subnormal serum TSH concentration in a patient with normal $\mathrm{T}_{4}$ and triiodothyronine $\left(\mathrm{T}_{3}\right)$ concentrations (Cooper \& Biondi 2012) - before becoming clinically hyperthyroid. In a recent prospective study of euthyroid geriatric cats, the annual incidence for development of hyperthyroidism was $7.4 \%$; cats that became hyperthyroid were much more likely to have both goiter and an undetectable serum TSH concentration at time of initial evaluation (Wakeling et al. 2011). Similarly, euthyroid human patients with subclinical hyperthyroidism associated with nodular goiter develop overt thyrotoxicosis at a similar rate of around 5-10\% per year (Hamburger 1980, Bartalena et al. 1991).

\section{Why has feline nodular goiter reached such epidemic proportions?}

There is much speculation regarding the cause of hyperthyroidism in cats and why it reached the epidemic proportions seen today. This has been variously attributed to an increase in feline longevity, increased willingness of owners to seek treatment for their cats, improved diagnosis by practicing veterinarians, or a true increase in disease prevalence. It seems likely that all are true to some extent. Epidemiological studies have found associations of hyperthyroidism with increasing age, a protective effect in certain pure breeds (notably the Siamese and Burmese), and associations with certain lifestyle factors, most notably living indoors, consumption of canned cat food (especially fish flavors), and the use of cat litter

Published by Bioscientifica Ltd 
(Scarlett 1988, Kass et al. 1999, Edinboro et al. 2004, Olczak et al. 2005, Wakeling et al. 2009).

Theories abound as to why canned food should increase the risk of developing hyperthyroidism. It could just be a marker for cats that are most likely to enjoy a protected indoor existence and, therefore, are most likely to live to an advanced age (when hyperthyroidism develops). However, this is unlikely to be the sole explanation. Historically, chronic dietary iodine deficiency has long been considered to be the major underlying risk factor for the development of toxic nodular goiter in human patients (Laurberg et al. 1991, Van de Ven et al. 2013). Interestingly, low-grade iodine deficiency has also been implicated to be one of the inciting causes for this condition in hyperthyroid cats (Edinboro et al. 2010, 2013). Therefore, iodine deficiency may play a role in development of feline nodular goiter, but, as in human patients with toxic nodular goiter, it is unlikely to be the only cause (Derwahl \& Studer 2000, 2001).

Other dietary factors that have been implicated in the pathogenesis of the feline toxic nodular goiter include dietary flavonoids, which are found in high concentrations in many cat foods (Court \& Freeman 2002, Bell et al. 2006). Flavonoids can act to inhibit thyroid peroxidase and have known goitrogenic properties (Divi \& Doerge 1996, Köhrle 2000, Doerge \& Sheehan 2002). In addition, flavonoids may have additional actions on the thyroid gland of cats, because the flavonoid quercetin was reported to induce autonomous mitogenesis and thyroglobulin synthesis in cultured feline hyperthyroid cells (Ward et al. 2010).

Chronic exposure to thyroid-disrupting compounds in the diet, drinking water, or environment may also play a role in the pathogenesis of feline thyroid nodules and hyperthyroidism, as postulated to occur in human thyroid disease (Diamanti-Kandarakis et al. 2009, Jugan et al. 2010, Zoeller 2010). For example, the polyphenolic compound bisphenol A, which is used as a plasticizer in can linings, has been detected in canned cat food and may act as a thyroid disruptor (Edinboro et al. 2004, Schecter et al. 2010). In a similar vein, recent studies both in the USA and Sweden have reported high levels of polybrominated diphenyl ethers (PBDEs) in cats, a fire-retardant with known thyroid-disrupting properties (Dye et al. 2007, Guo et al. 2012, Mensching et al. 2012, Norrgran et al. 2012). As PBDEs migrate out of the flame-protected materials (e.g. plastics, textiles, furniture, or electronics), these chemicals end up in house dust as the natural sink (Suzuki et al. 2008). Therefore, in addition to dietary sources of PBDEs, domestic cats living indoors and lying on the floor will normally collect dust in their fur and ingest these dust-enriched chemicals through grooming (Guo et al. 2012, Johnson et al. 2013). In the study of PBDEs and other endocrine-disrupting compounds, human beings and domestic cats share the same environments and tend to be chronically exposed to same chemical disruptors; however, because of their shorter life spans, companion animals may serve as good sentinels for human disease.

\section{Clinical features of toxic nodular goiter in cats}

In human patients, the two major risk factors for toxic nodular goiter include being older (over 60 years of age) and female (Siegel \& Lee 1998). As in human patients with toxic nodular goiter, hyperthyroidism occurs almost exclusively in the older to geriatric cat. Over $95 \%$ of cats will be older than 10 years at time of diagnosis (Mooney \& Peterson 2012, Peterson 2013a), which is equivalent to the human age at which risk of developing toxic nodular goiter increases (Vanderpump 2011, Paschke 2013). There is no breed predilection; although the disease does occur in pure breed cats, most cats with hyperthyroidism are of mixed-breeding (i.e. mongrel cats). Female cats also develop hyperthyroidism more commonly than males (1.25:1; Peterson et al. 1988, Peterson \& Becker 1995, Peterson \& Broome 2014b), although the female sex predilection is not as marked as in human patients with toxic nodular goiter ( $\geq 4: 1$; Vanderpump 2011, Paschke 2013).

In most cats with toxic nodular goiter, the recognition of hyperthyroidism is not difficult, and the clinical features closely parallel those of human hyperthyroid disease (Dabon-Almirante \& Surks 1998, Burch 2013). The classic clinical signs include weight loss together with a good to increased appetite (Mooney \& Peterson 2012, Peterson 2013a). Cats with severe hyperthyroidism will develop increased activity, nervousness, or restlessness, but milder cases do not generally show such symptoms. As in older human patients, some cats will develop an apathetic form of the disease, in which the appetite is reduced and lethargy, rather than hyperexcitability or nervousness, is noted (Mooney \& Peterson 2012, Peterson 2013a). Cardiac signs, including sinus tachycardia and cardiac murmur, are also very common in hyperthyroid cats, as these are in human patients with thyrotoxicosis (Klein \& Danzi 2007, Dahl et al. 2008). Occasionally vomiting, especially after overeating, is relatively common; other gastrointestinal signs, such as hyperdefecation or diarrhea, may also be reported. In some cats, dermatologic changes may develop as a result of an unkempt hair or

Published by Bioscientifica Ltd 
greasy hair coat will develop. If the disease is allowed to progress untreated, muscle wasting, fatigability, emaciation and cachexia will ultimately result, although this can take months to years (Fig. 8).

On physical examination, most cats have sinus tachycardia and show evidence of weight loss or loss of muscle mass. In addition, the finding of goiter is common (Boretti et al. 2009, Peterson 2013b). Cats have two separate thyroid lobes that normally lie on either side of the trachea, midway down the neck. Unlike that of man, the two feline thyroid lobes are separate and not connected via an isthmus (Dyce et al. 1987, Waters 1993). Goiter may be palpable in one or both lobes, and the thyroid nodules usually range in size from a pea to a grape, although much larger thyroid masses can be found. In cats with early or subclinical hyperthyroidism, the clinical signs are very mild or nonexistent other than the presence of one or two small thyroid nodule(s) (Norsworthy et al. 2002a, Ferguson \& Freeman 2006, Boretti et al. 2009).
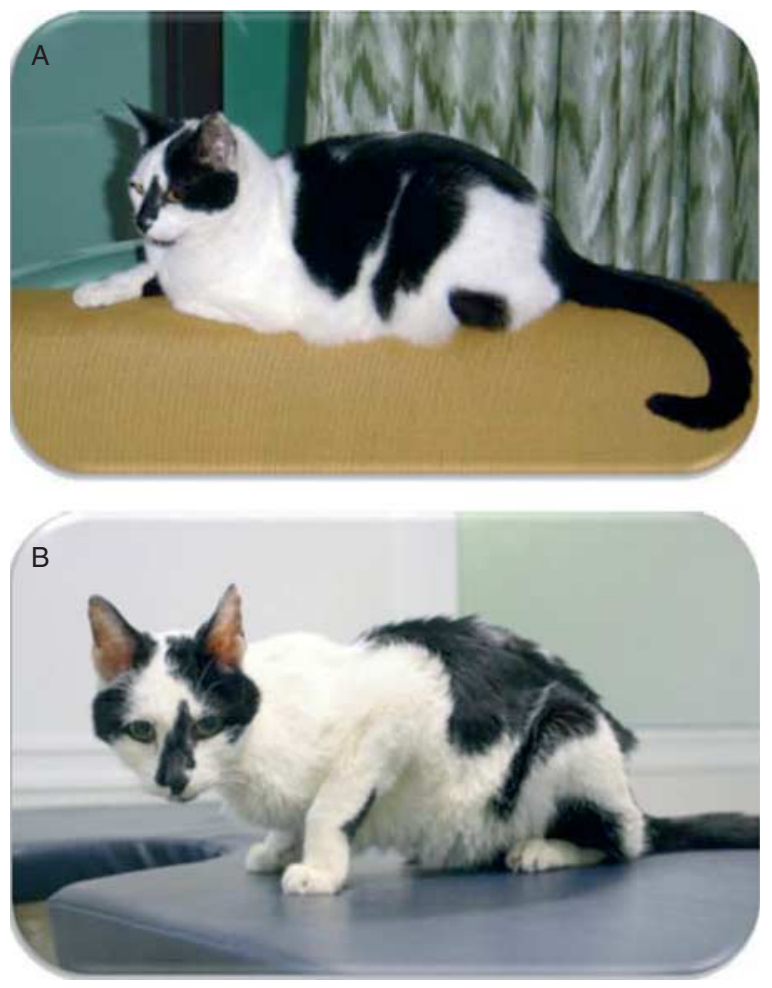

Figure 8

A female, domestic shorthaired cat at 9 years of age before hyperthyroidism (A) and again at 13 years of age after diagnosis of hyperthyroidism (B). At time of diagnosis, the owner reported gradual but progressive weight loss despite an increasing appetite for at least a year. Notice the marked weight loss and muscle wasting due to the untreated, long-standing toxic nodular goiter.

\section{Diagnostic evaluation of cats with toxic nodular goiter}

As in human patients, confirming the diagnosis of hyperthyroidism in cats requires use of one or more thyroid function tests to demonstrate increased circulating $\mathrm{T}_{4}$ and $\mathrm{T}_{3}$ concentrations, suppressed pituitary TSH secretion, or increased thyroidal radioisotope uptake. Thyroid imaging is also helpful to confirm the diagnosis, to determine the presence of ectopic or substernal extension of the nodular goiter, and to estimate the size of the goiter (Luster et al. 2010).

\section{Thyroidal radioisotope uptake}

Hyperthyroid cats usually exhibit increased thyroidal uptake of both radioactive iodine $\left({ }^{123} \mathrm{I}\right.$ or $\left.{ }^{131} \mathrm{I}\right)$ and technetium-99m as pertechnetate $\left({ }^{99 \mathrm{~m}} \mathrm{TcO}_{4}^{-}\right.$; Peterson et al. 1983, Sjollema et al. 1989, Mooney et al. 1992, Nap et al. 1994). Calculation of an increased value for thyroidto-salivary ratio also provide a sensitive means of diagnosing hyperthyroidism in cats (Peterson \& Broome 2014b), as has been reported in man (Sostre \& Parikh 1979, Anjos et al. 2006, Kandeel et al. 2009).

\section{Serum thyroid hormone and TSH concentrations}

In cats, as in man, the finding of high serum $T_{4}$ and $T_{3}$ concentrations is the biochemical hallmark of hyperthyroidism and is extremely specific for the diagnosis (Fig. 9A, B and C). In older cats presenting with classical clinical features of hyperthyroidism (e.g. weight loss despite a good appetite and palpable goiter), confirming the diagnosis is straightforward, as over $90 \%$ of hyperthyroid cats will have a serum total $\mathrm{T}_{4}$ concentration that is clearly high (Mooney et al. 1992, Peterson et al. 2001, Peterson $2013 b$,c). As measurement of total $\mathrm{T}_{4}$ is cheap and readily available, this has become the screening test of choice for cats with suspected hyperthyroidism. However, cats with subclinical hyperthyroidism have normal serum $\mathrm{T}_{4}$ and $\mathrm{T}_{3}$ values (Wakeling et al. 2007, 2011), and up to half of cats with early or mild hyperthyroidism have serum $\mathrm{T}_{4}$ within the reference interval limits (Peterson 2001, Peterson et al. 2001). In these cats, thyroid imaging or $\mathrm{T}_{3}$ suppression testing can be performed to aid in early diagnosis (Peterson et al. 1990, Peterson 2001, Peterson \& Broome 2014b). However, serum total $\mathrm{T}_{4}$ and $\mathrm{T}_{3}$ concentrations will eventually increase into the thyrotoxic range upon retesting a few weeks to months later as the goiter size continues to increase.

Published by Bioscientifica Ltd 

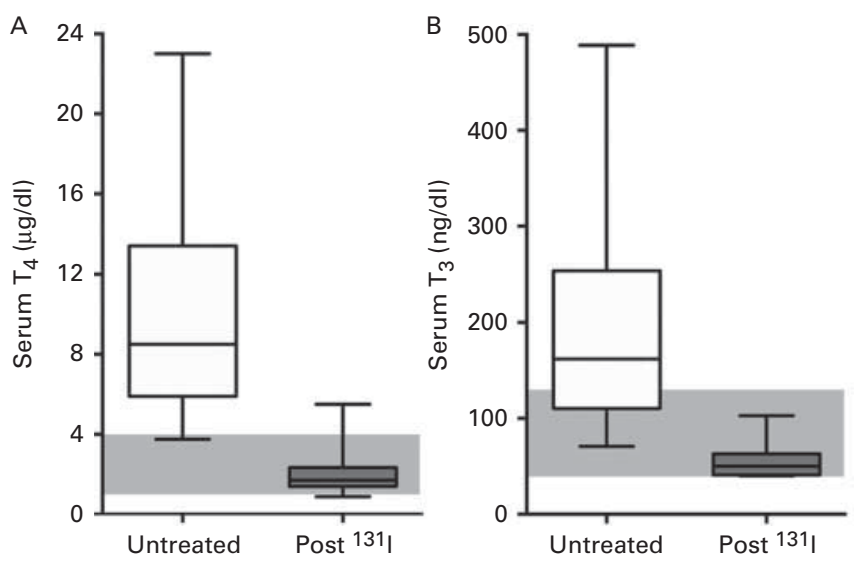

\section{Figure 9}

Serum concentrations of (A) $T_{4}(\mu \mathrm{g} / \mathrm{dl})$ ), (B) $T_{3}(\mathrm{ng} / \mathrm{dl})$ ), (C) free $T_{4}(\mathrm{pmol} / \mathrm{l})$, and (D) TSH $(\mathrm{ng} / \mathrm{ml})$ in 500 cats with toxic nodular goiter, before and after treatment with radioiodine. In each graph, the box represents the interquartile range (i.e. 25th-75th percentile range or the middle half of the data). The horizontal bar in the box represents the median value. For each box plot, the T-bars represent 5th-95th percentile. The shaded areas indicate the reference interval for each hormone. (A and B) Before treatment, notice that hyperthyroid cats have clearly high levels of both total $T_{4}$ and $T_{3}$, but some cats with mild hyperthyroidism may have values that remain within the reference interval. Also note that the reference intervals for total $\mathrm{T}_{4}$ and $\mathrm{T}_{3}$ in cats are $\sim 50 \%$ lower than the reference intervals in man (Kaptein et al. 1994, Davey 1997); the reason for this difference is that cats lack thyroxine-binding globulin (TBG), a major

In human patients, measurement of the circulating TSH concentration using a very sensitive third-generation assay is generally used as a first-line test for the assessment of thyroid function. The finding of a low to undetectable serum TSH value is consistent with a diagnosis of hyperthyroidism (Dabon-Almirante \& Surks 1998, Bahn et al. 2011). Although both $\alpha$ - and $\beta$-subunits of feline TSH have been cloned and sequenced (Rayalam et al. 2006a,b), a species-specific feline assay based on recognition of the $\beta$-subunit or heterodimer is not yet available. Most human TSH assays will not detect feline TSH, but canine TSH assays are commercially available and have been validated to measure feline TSH (Ferguson et al. 2007, Wakeling et al. $2007,2011)$. That a canine assay might detect feline TSH is perhaps not surprising, as feline TSH has a higher homology with canine TSH $(96 \% \quad \alpha$-subunit and 94\% $\beta$-subunit) than with human TSH (68\% $\alpha$-subunit and $88 \%$ B-subunit) (Rayalam et al. 2006b).

Untreated hyperthyroid cats have serum TSH concentrations at or below the detection limit, as might be expected (Fig. 9D). Unfortunately, the current commercial canine TSH assay (a first-generation assay) does not have the necessary test sensitivity to clearly distinguish normal feline TSH concentrations from low or undetectable TSH
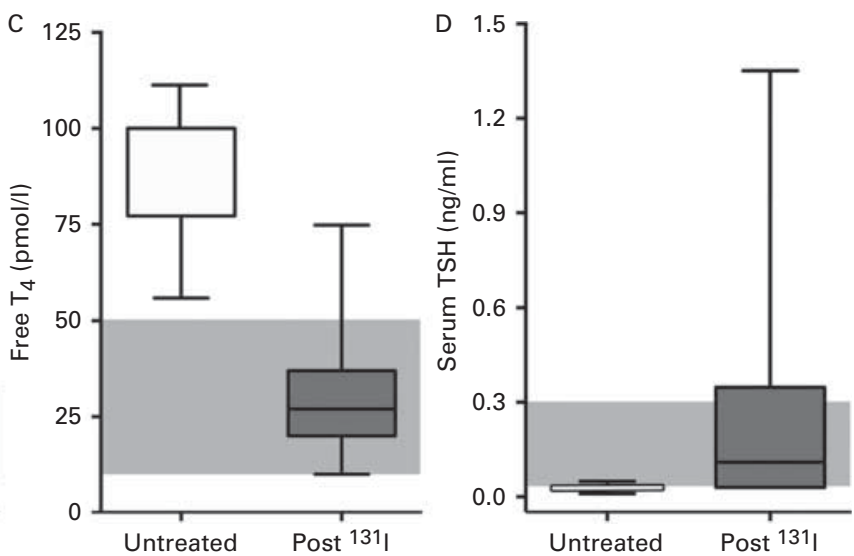

binding protein for both $\mathrm{T}_{4}$ and $\mathrm{T}_{3}$ in man (Larsson et al. 1985, Kaptein et al. 1994). Three months after treatment with radioiodine (post ${ }^{131} \mathrm{I}$ ), the high values have fallen into the reference interval. (C) Like total $T_{4}$, serum free $T_{4}$ concentration is high in almost all hyperthyroid cats and normalizes after treatment. As free $T_{4}$ methods measure the fraction of $T_{4}$ not bound by TBG or other serum proteins, this is considered a more accurate way to assess thyroid function in both cats and man (Davey 1997, Peterson et al. 2001, Thienpont et al. 2013). (D) Before treatment, serum TSH concentrations in the hyperthyroidism cat are low, at or below the level of quantification. After treatment the suppressed TSH values increase. Some of the ${ }^{131}$ I-treated cats develop mild to subclinical iatrogenic hypothyroidism, as evidenced by the high post-treatment TSH concentrations.

concentrations. In support of that, about half of older euthyroid cats we have evaluated have serum TSH values that were at or below the level of quantification. Clearly, a better TSH assay is needed to help in the diagnosis of cats with mild hyperthyroidism, specifically one that has adequate sensitivity and specificity for feline TSH to reliably distinguish a normal value in a euthyroid cat from a low value in a cat with toxic nodular goiter.

\section{Thyroid imaging}

As in human patients, it is difficult to estimate thyroid size or morphology in cats by neck palpation alone. Several imaging methods are available for thyroid imaging, including scintigraphy (with radioiodine or technetium; Daniel \& Neelis 2014, Peterson \& Broome 2014b), ultrasonography (Wisner 1994, Barberet et al. 2010), computed tomography scans (Drost et al. 2004, 2006), or magnetic resonance imaging (Hofmeister et al. 2001, Barthez et al. 2006).

Thyroid scintigraphy In cats, scintigraphy provides valuable information regarding both thyroid anatomy and physiology and plays an integral role in the diagnosis,

Published by Bioscientifica Ltd 
staging, and management of feline toxic nodular goiter. For hyperthyroid cats, scintigraphy is generally considered to be the thyroid imaging technique of choice for detecting and delineating all hyperfunctioning, adenomatous thyroid tissue. Advantages of nuclear scintigraphy include its ability to differentiate bilateral vs unilateral thyroid disease, assess thyroid size and activity, and identify ectopic or metastatic thyroid tissue (Daniel \& Neelis 2014, Peterson \& Broome 2014b).

In both humans and cats, the radionuclides most commonly used for thyroid scintigraphy are isotopes of radioactive iodine $\left({ }^{123} \mathrm{I}\right.$ or $\left.{ }^{131} \mathrm{I}\right)$ and sodium pertechnetate $\left({ }^{99} \mathrm{TcO}_{4}^{-}\right)$(Peterson \& Becker 1984, Daniel \& Brawnier 2006, Wahl 2013, Peterson \& Broome 2014b). Radioactive iodine, such as stable iodine, is trapped and concentrated within thyroid follicular cells by the sodium/iodine symporter (i.e. the iodine pump; Portulano et al. 2014). Once within the cell, iodine is oxidized to iodide as it passes though the thyroid follicular cell to the lumen of the thyroid follicle. Iodide is subsequently incorporated into tyrosine groups of thyroglobulin via organification; coupling of these iodotyrosyl groups forms $\mathrm{T}_{4}$ and $\mathrm{T}_{3}$, which are stored within the follicular colloid until secreted (Kopp 2013). Pertechnetate, such as iodine, is trapped and concentrated within thyroid follicular cells. Uptake of pertechnetate, however, reflects only the trapping mechanism of the thyroid gland; unlike stable and radioactive iodine, pertechnetate is neither organically bound to thyroglobulin nor stored in the thyroid gland.

A

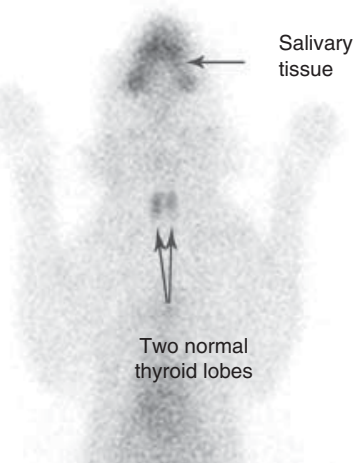

B

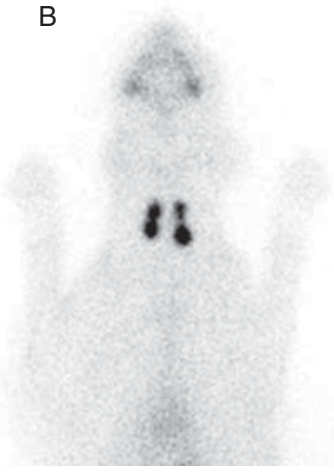

Because of these differences, the thyroid gland will initially take up pertechnetate just like radioiodine, but the peak uptake occurs sooner with pertechnetate $(20 \mathrm{~min}$ vs $8 \mathrm{~h}$ ), allowing an earlier imaging time after injection of radionuclide (Peterson \& Becker 1984, Daniel \& Brawnier 2006, Wahl 2013). This feature has made ${ }^{99 \mathrm{~m}} \mathrm{TcO}_{4}^{-}$the reference standard radionuclide for thyroid scintigraphy in veterinary medicine (Daniel \& Brawnier 2006, Daniel \& Neelis 2014, Peterson \& Broome 2014b).

In normal cats, the thyroid gland appears on thyroid scans as two well-defined, focal (ovoid) areas of radionuclide accumulation in the cranial to middle cervical region. The two separate thyroid lobes are symmetrical in size and shape and are located side-by-side (Fig. 10A; Daniel \& Brawnier 2006, Daniel \& Neelis 2014, Peterson \& Broome 2014b). As noted earlier, no connecting isthmus is found in the feline thyroid gland (Dyce et al. 1987, Waters 1993). The normal thyroid and salivary glands take up a similar amount of pertechnetate, resulting in a 1:1 brightness ratio. In addition to visual inspection, the percentage thyroidal uptake of the radioactive tracer and/or the thyroid:salivary ratio can be calculated; both provide an extremely sensitive means of diagnosing hyperthyroidism (Daniel \& Neelis 2014, Peterson \& Broome 2014b).

As in human patients with toxic nodular goiter, the scintigraphic image in cats generally shows a heterogeneous pattern of increased radionuclide uptake, most commonly into both thyroid lobes (Peterson \& Broome
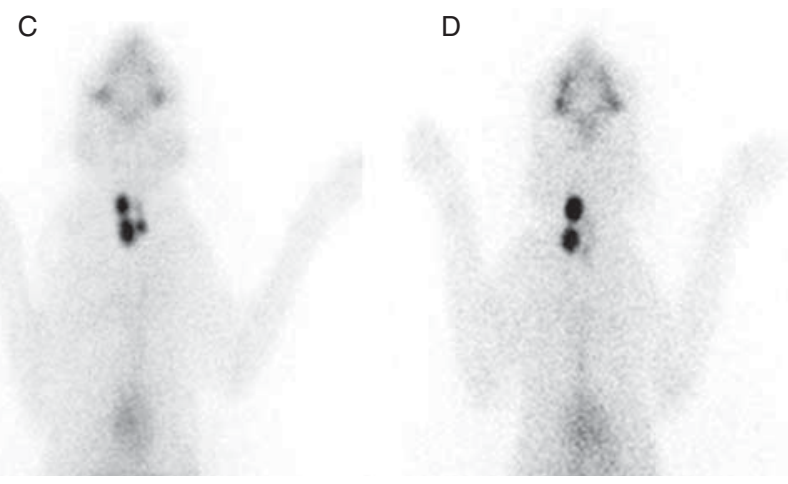

( $B, C$ and $D$ ) Image of the neck region of three cats with toxic nodular goiter. In cats $B$ and $C$, both thyroid lobes contain adenomatous nodules with a heterogeneous pattern of ${ }^{99} \mathrm{~m} \mathrm{TCO}_{4}{ }^{-}$uptake. In cat $\mathrm{D}$, the left thyroid lobe contains two large nodules, whereas the radionuclide uptake by the normal right thyroid lobe is decreased and cannot easily be visualized. For all three hyperthyroid cats, the uptake of the radionuclide by the hyperactive nodular goiter is higher than that by the salivary tissue. Both the calculated percent uptake of ${ }^{99 \mathrm{~m}} \mathrm{TcO}_{4}{ }^{-}$and the thyroid:salivary ratio were high, diagnostic for hyperthyroidism in all three cats.

Published by Bioscientifica Ltd http://joe.endocrinology-journals.org DOI: 10.1530/JOE-14-0461
(C) 2014 Society for Endocrinology Printed in Great Britain 
2014b; Fig. 10B, C and D). In cats with advanced nodular goiter and extensive autonomy, diffuse enlargement is seen, making it difficult to identify the adenomatous nodules on scintiscan. Similar finding are reported in human patients with advanced toxic nodular goiter (Meller et al. 2000, Meier \& Kaplan 2001, Sarkar 2006, Ianni et al. 2013).

\section{Treatment options for cats with toxic nodular goiter}

Treatment of toxic nodular goiter in cats is similar to that used in humans patients with hyperthyroidism (Freitas 2000, Rios et al. 2005, Barbaro et al. 2007, Porterfield et al. 2008, Szumowski et al. 2012, Paschke 2013), although it is easier for humans to take daily antithyroid tablets than it is for most owners to give daily medications to their cat. Broadly speaking, there are three options: medical management with methimazole or carbimazole, surgical thyroidectomy, or treatment with radioactive iodine. Less commonly used therapies include percutaneous ethanol or thermal ablation of the cat's thyroid nodules (Goldstein et al. 2001, Wells et al. 2001, Mallery et al. 2003) or nutritional management with the chronic feeding of an iodine-deficient prescription diet (van der Kooij et al. 2013, Fritsch et al. 2014). Each of these treatments has advantages and disadvantages (Mooney \& Peterson 2012, Daminet et al. 2014), which in many ways resemble those influencing treatment decisions in human patients with toxic nodular goiter.

As in the human disease, cats with toxic nodular goiter do not ever undergo spontaneous remission. Therefore, definitive therapy with radioiodine or thyroidectomy is usually recommended, especially if the cat is fairly young and healthy. However, in geriatric cats or in cats with concurrent nonthyroidal illness (chronic kidney disease is very common in older cats; Syme 2007), long-term antithyroid drug (methimazole) administration is frequently employed (Peterson et al. 1988, Mooney \& Peterson 2012, Peterson 2013a, Daminet et al. 2014). In addition, pretreatment with methimazole to restore euthyroidism prior surgery is a common practice for cats (Peterson et al. 1988, Mooney \& Peterson 2012). Hyperthyroid cats at increased risk for complications, including those with cardiovascular disease or severe hyperthyroidism, are sometimes treated with methimazole or $\beta$-adrenergic antagonists before definitive treatment with radioiodine. Such recommendations are similar to management guidelines established for human patients with toxic nodular goiter (Bahn et al. 2011).
Surgical thyroidectomy is associated with a high risk of recurrence if only a subtotal thyroidectomy is performed, because the disease is generally multinodular and involves both thyroid lobes (Welches et al. 1989, Swalec \& Birchard 1990). In addition, cats with large goiters may have thyroid tissue that descends through the thoracic inlet into the chest; in these cats with substernal disease, surgical removal may be difficult. Finally, about $4 \%$ of hyperthyroid cats have adenomatous tissue in ectopic sites (lingual or substernal sites are most common), which would likely be missed at surgery (Peterson \& Broome 2014b). Because of the short-half life of $\mathrm{T}_{4}$ and $\mathrm{T}_{3}$ in cats (Kaptein et al. 1994), euthyroidism after successful thyroidectomy can usually be achieved within $24-48 \mathrm{~h}$ after surgery. As in human patients, iatrogenic hypothyroidism and hypoparathyroidism are potential complications of total thyroidectomy in cats (Welches et al. 1989, Birchard 2006, Naan et al. 2006, Mooney \& Peterson 2012).

Most authorities agree that radioiodine is the treatment of choice for most cats with toxic nodular goiter, as is commonly recommended in human patients. However, the relatively high cost and the long isolation period for cats after treatment (hospitalization times range from 3 days to 4 weeks dependent on the local radiation safety rules) are major disadvantages. The success rate of ${ }^{131} \mathrm{I}$ therapy in cats is very high, over 95\% in most studies (Peterson \& Becker 1995, Peterson \& Broome 2014c). Again, because of the of the short half-life of $\mathrm{T}_{4}$ and $\mathrm{T}_{3}$ in cats (Kaptein et al. 1994), euthyroidism is generally restored by 1-3 months after treatment. The prevalence of hypothyroidism in these cats ranges from $10 \%$ up to $75 \%$, depending on the dose administered (Williams et al. 2010, Peterson 2014).

\section{Conclusions and future perspectives}

Naturally occurring hyperthyroidism is a very common endocrinopathy in the cat, with close parallels to toxic nodular goiter in humans. Diagnosis and treatment of this condition are relatively straightforward and can be similarly successful in veterinary practice. What is not known is why the condition develops, or why its prevalence has continued to increase over the last 35 years to reach the near epidemic proportions seen today. Various nutritional and environmental risk factors have been suggested to contribute to the disease pathogenesis, and it may be that the cat is acting as a 'sentinel', alerting us to the potential danger to humans from exposure to environmental pollutants. Because of its impact on feline

Published by Bioscientifica Ltd 
health and similarity with human disease, further study into the nutritional, cellular, and molecular mechanisms of feline toxic nodular goiter is important to our understanding of this disease and other hyperfunctioning endocrine diseases in both animals and man.

\section{Declaration of interest}

The author declares that there is no conflict of interest that could be perceived as prejudicing the impartiality of this review.

\section{Funding}

This review did not receive any specific grant from any funding agency in the public, commercial or not-for-profit sector.

\section{Acknowledgements}

The author acknowledges Carol Castellano for editing and critical reading of the manuscript.

\section{References}

Aghini-Lombardi F, Antonangeli L, Martino E, Vitti P, Maccherini D, Leoli F, Rago T, Grasso L, Valeriano R, Balestrieri A et al. 1999 The spectrum of thyroid disorders in an iodine-deficient community: the Pescopagano survey. Journal of Clinical Endocrinology and Metabolism 84 561-566. (doi:10.1210/jcem.84.2.5508)

American Veterinary Medical Association 2012 U.S. Pet Ownership \& Demographic Sourcebook. Schaumburg, IL, USA: American Veterinary Medical Association.

Anjos DA, Etchebehere EC, Santos AO, Lima MC, Ramos CD, Paula RB \& Camargo EE 2006 Normal values of $\left[{ }^{99 m} \mathrm{Tc}\right]$ pertechnetate uptake and excretion fraction by major salivary glands. Nuclear Medicine Communications 27 395-403. (doi:10.1097/01.mnm.0000202864.52046.b1)

Bahn RS, Burch HB, Cooper DS, Garber JR, Greenlee MC, Klein I, Laurberg P, McDougall IR, Montori VM, Rivkees SA et al. 2011 Hyper-

thyroidism and other causes of thyrotoxicosis: management guidelines of the American Thyroid Association and American Association of Clinical Endocrinologists. Endocrine Practice 17 456-520. (doi:10.4158/ EP.17.3.456)

Barbaro D, Orsini P, Lapi P, Pasquini C, Tuco A, Righini A \& Lemmi P 2007 Percutaneous laser ablation in the treatment of toxic and pretoxic nodular goiter. Endocrine Practice 13 30-36. (doi:10.4158/EP.13.1.30)

Barberet V, Baeumlin Y, Taeymans O, Duchateau L, Peremans K, van Hoek I, Daminet S \& Saunders JH 2010 Pre- and posttreatment ultrasonography of the thyroid gland in hyperthyroid cats. Veterinary Radiology \& Ultrasound 51 324-330. (doi:10.1111/j.1740-8261.2009.01656.x)

Bartalena L, Martino E, Velluzzi F, Piga M, Petrini L, Loviselli A, Grasso L \& Pinchera A 1991 The lack of nocturnal serum thyrotropin surge in patients with nontoxic nodular goiter may predict the subsequent occurrence of hyperthyroidism. Journal of Clinical Endocrinology and Metabolism 73 604-608. (doi:10.1210/jcem-73-3-604)

Barthez PY, Schaafsma IA \& Pollak YW 2006 Multimodality image fusion to facilitate anatomic localization of ${ }^{99} \mathrm{~m}$ TC-pertechnetate uptake in the feline head. Veterinary Radiology \& Ultrasound 47 503-506. (doi:10.1111/j.1740-8261.2006.00176.x)

Bell KM, Rutherfurd SM \& Hendriks WH 2006 The isoflavone content of commercially-available feline diets in New Zealand. New
Zealand Veterinary Journal 54 103-108. (doi:10.1080/00480169. 2006.36620)

Birchard SJ 2006 Thyroidectomy in the cat. Clinical Techniques in Small Animal Practice 21 29-33. (doi:10.1053/j.ctsap.2005.12.005)

Boretti FS, Sieber-Ruckstuhl NS, Gerber B, Laluha P, Baumgartner C, Lutz H, Hofmann-Lehmann R \& Reusch CE 2009 Thyroid enlargement and its relationship to clinicopathological parameters and $\mathrm{T} 4$ status in suspected hyperthyroid cats. Journal of Feline Medicine and Surgery $\mathbf{1 1}$ 286-292. (doi:10.1016/j.jfms.2008.08.002)

Broome MR \& Peterson ME 2014 Treatment of severe, unresponsive, or recurrent hyperthyroidism. In August's Consultations in Feline Internal Medicine. Ed SE Little. Philadelphia, PA, USA: Elsevier [in press].

Brown RS 1995 Immunoglobulins affecting thyroid growth: a continuing controversy. Journal of Clinical Endocrinology and Metabolism 80 1506-1508. (doi:10.1210/jcem.80.5.7744993)

Brown RS, Keating P, Livingston PG \& Bullock L 1992 Thyroid growth immunoglobulins in feline hyperthyroidism. Thyroid 2 125-130. (doi:10.1089/thy.1992.2.125)

Burch HB 2013 Overview of the clinical manifestations of thyrotoxicosis. In Werner \& Ingbar's The Thyroid: A Fundamental and Clinical Text, 10th edn, pp 434-440. Eds LE Braverman \& DS Cooper. Philadelphia, PA, USA: Lippincott Williams \& Wilkins.

Capen CC 2001 Overview of structural and functional lesions in endocrine organs of animals. Toxicologic Pathology 29 8-33. (doi:10.1080/ 019262301301418829)

Carpenter JL, Andrews LK \& Holzworth J 1987 Tumors and tumor-like lesions. In Diseases of the Cat: Medicine and Surgery, pp 406-596. Ed J Holzworth. Philadelphia, PA, USA: W.B. Saunders.

Cerci C, Cerci SS, Eroglu E, Dede M, Kapucuoglu N, Yildiz M \& Bulbul M 2007 Thyroid cancer in toxic and non-toxic multinodular goiter. Journal of Postgraduate Medicine 53 157-160. (doi:10.4103/0022-3859.33855)

Chaitman J, Hess R, Senz R, Van Winkle T \& Ward CR 1999 Thyroid adenomatous hyperplasia in euthyroid cats. Journal of Veterinary Internal Medicine 13 242. (doi:10.1177/1098612X12464462)

Cooper DS \& Biondi B 2012 Subclinical thyroid disease. Lancet 379 1142-1154. (doi:10.1016/S0140-6736(11)60276-6)

Court MH \& Freeman LM 2002 Identification and concentration of soy isoflavones in commercial cat foods. American Journal of Veterinary Research 63 181-185. (doi:10.2460/ajvr.2002.63.181)

Dabon-Almirante CL \& Surks MI 1998 Clinical and laboratory diagnosis of thyrotoxicosis. Endocrinology and Metabolism Clinics of North America 27 25-35. (doi:10.1016/S0889-8529(05)70295-4)

Dahl P, Danzi S \& Klein I 2008 Thyrotoxic cardiac disease. Current Heart Failure Reports 5 170-176. (doi:10.1007/s11897-008-0026-9)

Daminet S, Kooistra HS, Fracassi F, Graham PA, Hibbert A, Lloret A, Mooney CT, Neiger R, Rosenberg D, Syme HM et al. 2014 Best practice for the pharmacological management of hyperthyroid cats with antithyroid drugs. Journal of Small Animal Practice 55 4-13. (doi:10.1111/jsap.12157)

Daniel GB \& Brawnier WR 2006 Thyroid scintigraphy. In Textbook of Veterinary Nuclear Medicine, 2nd edn, pp 181-199. Eds GB Daniel \& CR Berry. Harrisburg, PA, USA: American College of Veterinary Radiology.

Daniel GB \& Neelis DA 2014 Thyroid scintigraphy in veterinary medicine. Seminars in Nuclear Medicine 44 24-34. (doi:10.1053/j.semnuclmed. 2013.08.007)

Davey R 1997 Thyroxine, thyrotropin, and age in a euthyroid hospital patient population. Clinical Chemistry 43 2143-2148.

Delemer B, Dib K, Patey M, Jacquemin C \& Correze C 1992 Modification of the amounts of $\mathrm{G}$ proteins and of the activity of adenylyl cyclase in human benign thyroid tumours. Journal of Endocrinology 132 477-485. (doi:10.1677/joe.0.1320477)

Derwahl M \& Studer H 2000 Multinodular goitre: 'much more to it than simply iodine deficiency'. Baillière's Best Practice \& Research. Clinical Endocrinology \& Metabolism 14 577-600. (doi:10.1053/beem. 2000.0104) 
Derwahl M \& Studer H 2001 Nodular goiter and goiter nodules: where iodine deficiency falls short of explaining the facts. Experimental and Clinical Endocrinology \& Diabetes 109 250-260. (doi:10.1055/s-2001-16344)

Derwahl M \& Studer H 2002 Hyperplasia versus adenoma in endocrine tissues: are they different? Trends in Endocrinology and Metabolism 13 23-28. (doi:10.1016/S1043-2760(01)00519-7)

Derwahl M, Hamacher C, Russo D, Broecker M, Manole D, Schatz H, Kopp P \& Filetti S 1996 Constitutive activation of the Gs $\alpha$ protein-adenylate cyclase pathway may not be sufficient to generate toxic thyroid adenomas. Journal of Clinical Endocrinology and Metabolism 81 1898-1904. (doi:10.1210/jcem.81.5.8626855)

Diamanti-Kandarakis E, Bourguignon JP, Giudice LC, Hauser R, Prins GS, Soto AM, Zoeller RT \& Gore AC 2009 Endocrine-disrupting chemicals: an Endocrine Society scientific statement. Endocrine Reviews 30 293-342. (doi:10.1210/er.2009-0002)

Divi RL \& Doerge DR 1996 Inhibition of thyroid peroxidase by dietary flavonoids. Chemical Research in Toxicology 9 16-23. (doi:10.1021/ tx950076m)

Doerge DR \& Sheehan DM 2002 Goitrogenic and estrogenic activity of soy isoflavones. Environmental Health Perspectives 110(Suppl 3) 349-353. (doi:10.1289/ehp.02110s3349)

Drost WT, Mattoon JS, Samii VF, Weisbrode SE \& Hoshaw-Woodard SL 2004 Computed tomographic densitometry of normal feline thyroid glands. Veterinary Radiology \& Ultrasound 45 112-116. (doi:10.1111/ j.1740-8261.2004.04018.x)

Drost WT, Mattoon JS \& Weisbrode SE 2006 Use of helical computed tomography for measurement of thyroid glands in clinically normal cats. American Journal of Veterinary Research 67 467-471. (doi:10.2460/ ajvr.67.3.467)

Dumont JE, Lamy F, Roger P \& Maenhaut C 1992 Physiological and pathological regulation of thyroid cell proliferation and differentiation by thyrotropin and other factors. Physiological Reviews 72 667-697.

Duprez L, Hermans J, Van Sande J, Dumont JE, Vassart G \& Parma J 1997 Two autonomous nodules of a patient with multinodular goiter harbor different activating mutations of the thyrotropin receptor gene. Journal of Clinical Endocrinology and Metabolism 82 306-308. (doi:10.1210/jcem.82.1.3691)

Dyce KM, Sack WO \& Wensing CJG 1987 The endocrine glands. In Textbook of Veterinary Anatomy, pp 205-211. Eds KM Dyce, WO Sack \& CJG Wensing. Philadelphia, PA, USA: W.B. Saunders.

Dye JA, Venier M, Zhu L, Ward CR, Hites RA \& Birnbaum LS 2007 Elevated PBDE levels in pet cats: sentinels for humans? Environmental Science \& Technology 41 6350-6356. (doi:10.1021/es0708159)

Edinboro CH, Scott-Moncrieff JC, Janovitz E, Thacker HL \& Glickman LT 2004 Epidemiologic study of relationships between consumption of commercial canned food and risk of hyperthyroidism in cats. Journal of the American Veterinary Medical Association 224 879-886. (doi:10.2460/ javma.2004.224.879)

Edinboro CH, Scott-Moncrieff JC \& Glickman LT 2010 Feline hyperthyroidism: potential relationship with iodine supplement requirements of commercial cat foods. Journal of Feline Medicine and Surgery 12 672-679. (doi:10.1016/j.jfms.2010.07.011)

Edinboro CH, Pearce EN, Pino S \& Braverman LE 2013 Iodine concentration in commercial cat foods from three regions of the USA, 2008-2009. Journal of Feline Medicine and Surgery 15 717-724. (doi:10.1177/1098612X13477855)

Ferguson D \& Freeman R 2006 Goiter in apparently euthyroid cats. In Consultations in Feline Internal Medicine, 5th edn, pp 207-215. Ed JR August. St. Louis, MO, USA: Elsevier Saunders.

Ferguson DC, Caffall Z \& Hoenig M 2007 Obesity increases free thyroxine proportionally to nonesterified fatty acid concentrations in adult neutered female cats. Journal of Endocrinology 194 267-273. (doi:10.1677/JOE-07-0064)

Freitas JE 2000 Therapeutic options in the management of toxic and nontoxic nodular goiter. Seminars in Nuclear Medicine 30 88-97. (doi:10.1053/nm.2000.4597)
Fritsch DA, Allen TA, Dodd DE, Wedekind KJ \& Sixby KA 2014 A restricted iodine food reduces circulating thyroxine concentrations in cats with hyperthyroidism. International Journal of Applied Research in Veterinary Medicine 12 24-32. (doi:10.1177/1098612X13512627)

Fuhrer D, Holzapfel HP, Wonerow P \& Paschke R 1996 Constitutively activating mutations of the thyrotropin receptor and thyroid disease. European Journal of Medical Research 1 460-464.

Gandolfi PP, Frisina A, Raffa M, Renda F, Rocchetti O, Ruggeri C \& Tombolini A 2004 The incidence of thyroid carcinoma in multinodular goiter: retrospective analysis. Acta Bio-medica: Atenei Parmensis 75 114-117.

Gerber H, Studer H \& von Grunigen C 1985 Paradoxical effects of thyrotropin on diffusion of thyroglobulin in the colloid of rat thyroid follicles after long term thyroxine treatment. Endocrinology 116 303-310. (doi:10.1210/endo-116-1-303)

Gerber H, Peter HJ, Bösiger J, Studer H, Drews R, Ferguson DC, Peterson ME \& Becker DV 1991 Different continuous cell lines from adenomatous feline goiters widely differ in morphologic, functional and growth parameters. In Progress in Thyroid Research, pp 541-544. Eds A Gordon, J Gross \& G Hennemann. Rotterdam, Netherlands: Balkema.

Gerber H, Peter H, Ferguson DC \& Peterson ME 1994 Etiopathology of feline toxic nodular goiter. Veterinary Clinics of North America. Small Animal Practice 24 541-565.

Gerber H, Wagner HE, Burgi U \& Peter HJ 1996 Model of the athymic nude mouse for the study of benign goiter disease. Experimental and Clinical Endocrinology \& Diabetes 104(Suppl 3) 56-59. (doi:10.1055/ s-0029-1211688)

Gójska-Zygner O, Lechowski R \& Zygner W 2014 Prevalence of feline hyperthyroidism in mature cats in urban population in Warsaw. Bulletin of the Veterinary Institute in Pulawy 58 267-271. (doi:10.2478/ bvip-2014-0040)

Goldstein RE, Long C, Swift NC, Hornof WJ, Nelson RW, Nyland TG \& Feldman EC 2001 Percutaneous ethanol injection for treatment of unilateral hyperplastic thyroid nodules in cats. Journal of the American Veterinary Medical Association 218 1298-1302. (doi:10.2460/javma. 2001.218.1298)

Guo W, Park JS, Wang Y, Gardner S, Baek C, Petreas M \& Hooper K 2012 High polybrominated diphenyl ether levels in California house cats: house dust a primary source? Environmental Toxicology and Chemistry 31 301-306. (doi:10.1002/etc.1700)

Hamburger JI 1980 Evolution of toxicity in solitary nontoxic autonomously functioning thyroid nodules. Journal of Clinical Endocrinology and Metabolism 50 1089-1093. (doi:10.1210/jcem-50-6-1089)

Hammer KB, Holt DE \& Ward CR 2000 Altered expression of G proteins in thyroid gland adenomas obtained from hyperthyroid cats. American Journal of Veterinary Research 61 874-879. (doi:10.2460/ajvr.2000.61.874)

Hibbert A, Gruffydd-Jones T, Barrett EL, Day MJ \& Harvey AM 2009 Feline thyroid carcinoma: diagnosis and response to high-dose radioactive iodine treatment. Journal of Feline Medicine and Surgery 11 116-124. (doi:10.1016/j.jfms.2008.02.010)

Hoenig M, Goldschmidt MH, Ferguson DC, Koch K \& Eymontt MJ 1982 Toxic nodular goitre in the cat. Journal of Small Animal Practice 23 1-12. (doi:10.1111/j.1748-5827.1982.tb01629.x)

Hofmeister E, Kippenes H, Mealey KL, Cantor GH \& Lohr CV 2001 Functional cystic thyroid adenoma in a cat. Journal of the American Veterinary Medical Association 219 190-193. (doi:10.2460/javma.2001. 219.190)

Holzapfel HP, Fuhrer D, Wonerow P, Weinland G, Scherbaum WA \& Paschke R 1997 Identification of constitutively activating somatic thyrotropin receptor mutations in a subset of toxic multinodular goiters. Journal of Clinical Endocrinology and Metabolism 82 4229-4233. (doi:10.1210/jcem.82.12.4441)

Holzapfel HP, Bergner B, Wonerow P \& Paschke R 2002 Expression of Gas proteins and TSH receptor signalling in hyperfunctioning thyroid nodules with TSH receptor mutations. European Journal of Endocrinology 147 109-116. (doi:10.1530/eje.0.1470109) 
Ianni F, Perotti G, Prete A, Paragliola RM, Ricciato MP, Carrozza C, Salvatori M, Pontecorvi A \& Corsello SM 2013 Thyroid scintigraphy: an old tool is still the gold standard for an effective diagnosis of autonomously functioning thyroid nodules. Journal of Endocrinological Investigation 36 233-236. (doi:10.3275/8471)

Johnson PI, Stapleton HM, Mukherjee B, Hauser R \& Meeker JD 2013 Associations between brominated flame retardants in house dust and hormone levels in men. Science of the Total Environment $\mathbf{4 4 5 - 4 4 6}$ 177-184. (doi:10.1016/j.scitotenv.2012.12.017)

Jugan ML, Levi Y \& Blondeau JP 2010 Endocrine disruptors and thyroid hormone physiology. Biochemical Pharmacology 79 939-947. (doi:10.1016/j.bcp.2009.11.006)

Kandeel AA, Wagih S, Mahassen A, Abo-Fabal MD \& Qassem KF 2009 Thyroid uptake versus thyroid salivary ratios: which is more reliable for post-operative thyroid functional assessment in patients with recurrent hyperthyroidism? Medical Journal of Cairo University 77 227-231.

Kaptein EM, Hays MT \& Ferguson DC 1994 Thyroid hormone metabolism. A comparative evaluation. Veterinary Clinics of North America. Small Animal Practice 24 431-466.

Kass PH, Peterson ME, Levy J, James K, Becker DV \& Cowgill LD 1999 Evaluation of environmental, nutritional, and host factors in cats with hyperthyroidism. Journal of Veterinary Internal Medicine 13 323-329. (doi:10.1111/j.1939-1676.1999.tb02189.x)

Kennedy RL \& Thoday KL 1988 Autoantibodies in feline hyperthyroidism. Research in Veterinary Science $\mathbf{4 5}$ 300-306.

Kennedy RL \& Thoday KL 1989 Lack of thyroid stimulatory activity in the serum of hyperthyroid cats. Autoimmunity 3 317-318. (doi:10.3109/ 08916938908997102)

Khan A \& Nose V 2010 Pathology of thyroid gland. In Endocrine Pathology: Differential Diagnosis and Molecular Advances, 2nd edn, pp 181-236. Ed RV Lloyd. New York, NY, USA: Springer.

Klein I \& Danzi S 2007 Thyroid disease and the heart. Circulation 116 1725-1735. (doi:10.1161/CIRCULATIONAHA.106.678326)

Kleinau G, Neumann S, Gruters A, Krude H \& Biebermann H 2013 Novel insights on thyroid-stimulating hormone receptor signal transduction. Endocrine Reviews 34 691-724. (doi:10.1210/er.2012-1072)

Köhrle J 2000 Flavonoids as a risk factor for goiter and hypothyroidism. In The Thyroid and Environment. Proceedings of the Merck European Thyroid Symposium, pp 41-63. Eds F Péter, WM Wiersinga \& U Hostalek. Stuttgart, Germany: Schattaue.

van der Kooij M, Becvarova I, Meyer HP, Teske E \& Kooistra HS 2013 Effects of an iodine-restricted food on client-owned cats with hyperthyroidism. Journal of Feline Medicine and Surgery 14 491-498. (doi:10.1177/1098612X13512627)

Kopp P 2001 The TSH receptor and its role in thyroid disease. Cellular and Molecular Life Sciences 58 1301-1322. (doi:10.1007/PL00000941)

Kopp P 2013 Thyroid hormone synthesis. In Werner \& Ingbar's The Thyroid: A Fundamental and Clinical Text, 10th edn, pp 48-74. Eds LE Braverman \& DS Cooper. Philadelphia, PA, USA: Lippincott Williams \& Wilkins.

Krohn K \& Paschke R 2002 Somatic mutations in thyroid nodular disease. Molecular Genetics and Metabolism 75 202-208. (doi:10.1006/mgme. 2001.3290)

Krohn K, Fuhrer D, Bayer Y, Eszlinger M, Brauer V, Neumann S \& Paschke R 2005 Molecular pathogenesis of euthyroid and toxic multinodular goiter. Endocrine Reviews 26 504-524. (doi:10.1210/er.2004-0005)

Larsson M, Pettersson T \& Carlstrom A 1985 Thyroid hormone binding in serum of 15 vertebrate species: isolation of thyroxine-binding globulin and prealbumin analogs. General and Comparative Endocrinology $\mathbf{5 8}$ 360-375. (doi:10.1016/0016-6480(85)90108-X)

Laurberg P, Pedersen KM, Vestergaard H \& Sigurdsson G 1991 High incidence of multinodular toxic goitre in the elderly population in a low iodine intake area vs. high incidence of Graves' disease in the young in a high iodine intake area: comparative surveys of thyrotoxicosis epidemiology in East-Jutland Denmark and Iceland. Journal of Internal Medicine 229 415-420. (doi:10.1111/j.1365-2796.1991. tb00368.x)
Leav I, Schiller AL, Rijnberk A, Legg MA \& der Kinderen PJ 1976 Adenomas and carcinomas of the canine and feline thyroid. American Journal of Pathology 83 61-122.

Liu C, Wu C, Wang F \& Zhou M 2010 Mutations of GNAS and TSHR genes in subclinical toxic multinodular goiter. Annals of Otology, Rhinology, and Laryngology 119 118-124.

Lucke VM 1964 An histological study of thyroid abnormalities in the domestic cat. Journal of Small Animal Practice 5 351-358. (doi:10.1111/ j.1748-5827.1964.tb04261.x)

Luster M, Verburg FA \& Scheidhauer K 2010 Diagnostic imaging work up in multi-nodular goiter. Minerva Endocrinologica 35 153-159.

Mallery KF, Pollard RE, Nelson RW, Hornof WJ \& Feldman EC 2003 Percutaneous ultrasound-guided radiofrequency heat ablation for treatment of hyperthyroidism in cats. Journal of the American Veterinary Medical Association 223 1602-1607. (doi:10.2460/javma.2003.223.1602)

Meier DA \& Kaplan MM 2001 Radioiodine uptake and thyroid scintiscanning. Endocrinology and Metabolism Clinics of North America 30 291-313. (doi:10.1016/S0889-8529(05)70188-2)

Meller J, Wisheu S, Munzel U, Behe M, Gratz S \& Becker W 2000 Radioiodine therapy for Plummer's disease based on the thyroid uptake of technetium-99m pertechnetate. European Journal of Nuclear Medicine 27 1286-1291. (doi:10.1007/s002590000285)

Menconi F, Marcocci C \& Marino M 2014 Diagnosis and classification of Graves' disease. Autoimmunity Reviews 13 398-402. (doi:10.1016/ j.autrev.2014.01.013)

Mensching DA, Slater M, Scott JW, Ferguson DC \& Beasley VR 2012 The feline thyroid gland: a model for endocrine disruption by polybrominated diphenyl ethers (PBDEs)? Journal of Toxicology and Environmental Health 75 201-212. (doi:10.1080/15287394.2012.652054)

Miller JM \& Kawas B 1966 The combined use of iodine-125 and iodine-131 in autoradiographic studies of nodular goiter. Journal of Nuclear Medicine 7 188-196.

Miyamoto T, Ikuko M, Kenji K, Yuka K, Hiroyuki T, Kazumi S \& Eiichiro B 2002 Prevalence of feline hyperthyroidism in Osaka and the Chugoku region. Journal of the Japan Veterinary Medical Association 55 289-292.

Mooney CT \& Peterson ME 2012 Feline hyperthyroidism. In Manual of Canine and Feline Endocrinology, 4th edn, pp 199-203. Eds CT Mooney \& ME Peterson. Quedgeley, Gloucester, UK: British Small Animal Veterinary Association.

Mooney CT, Thoday JL, Nicoll JJ \& Doxey DL 1992 Qualitative and quantitative thyroid imaging in feline hyperthyroidism using technetium-99m as pertechnetate. Veterinary Radiology \& Ultrasound $\mathbf{3 3}$ 313-320. (doi:10.1111/j.1740-8261.1992.tb00149.x)

Naan EC, Kirpensteijn J, Kooistra HS \& Peeters ME 2006 Results of thyroidectomy in 101 cats with hyperthyroidism. Veterinary Surgery 35 287-293. (doi:10.1111/j.1532-950X.2006.00146.x)

Nap AM, Pollak YW, van den Brom WE \& Rijnberk A 1994 Quantitative aspects of thyroid scintigraphy with pertechnetate $\left({ }^{99 \mathrm{~m}} \mathrm{TcO}_{4}^{-}\right)$in cats. Journal of Veterinary Internal Medicine 8 302-303. (doi:10.1111/j.19391676.1994.tb03238.x)

Nguyen LQ, Arseven OK, Gerber H, Stein BS, Jameson JL \& Kopp P 2002 Cloning of the cat TSH receptor and evidence against an autoimmune etiology of feline hyperthyroidism. Endocrinology 143 395-402. (doi:10.1210/endo.143.2.8622)

Nishihara E, Amino N, Maekawa K, Yoshida H, Ito M, Kubota S, Fukata S \& Miyauchi A 2009 Prevalence of TSH receptor and Gs $\alpha$ mutations in 45 autonomously functioning thyroid nodules in Japan. Endocrine Journal 56 791-798. (doi:10.1507/endocri.K09E-073)

Norrgran J, Jones B, Lindquist NG \& Bergman A 2012 Decabromobiphenyl, polybrominated diphenyl ethers, and brominated phenolic compounds in serum of cats diagnosed with the endocrine disease feline hyperthyroidism. Archives of Environmental Contamination and Toxicology 63 161-168. (doi:10.1007/s00244-012-9750-y)

Norsworthy GD, Adams VJ, McElhaney MR \& Milios JA 2002a Relationship between semi-quantitative thyroid palpation and total thyroxine concentration in cats with and without hyperthyroidism. 
Journal of Feline Medicine and Surgery 4 139-143. (doi:10.1053/jfms.2001. 0164)

Norsworthy GD, Adams VJ, McElhaney MR \& Milios JA 2002b Palpable thyroid and parathyroid nodules in asymptomatic cats. Journal of Feline Medicine and Surgery 4 145-151. (doi:10.1053/jfms.2001.0163)

Olczak J, Jones BR, Pfeiffer DU, Squires RA, Morris RS \& Markwell PJ 2005 Multivariate analysis of risk factors for feline hyperthyroidism in New Zealand. New Zealand Veterinary Journal 53 53-58. (doi:10.1080/ 00480169.2005.36469)

Parma J, Duprez L, Van Sande J, Hermans J, Rocmans P, Van Vliet G, Costagliola S, Rodien P, Dumont JE \& Vassart G 1997 Diversity and prevalence of somatic mutations in the thyrotropin receptor and $\mathrm{Gs} \alpha$ genes as a cause of toxic thyroid adenomas. Journal of Clinical Endocrinology and Metabolism 82 2695-2701.

Paschke R 2013 Toxic adenoma and toxic multinodular goiter. In Werner \& Ingbar's The Thyroid: A Fundamental and Clinical Text, 10th edn, pp 400-408. Eds LE Braverman \& DS Cooper. Philadelphia, PA, USA: Lippincott Williams \& Wilkins.

Pearce SH, Foster DJ, Imrie H, Myerscough N, Beckett GJ, Thoday KL \& Kendall-Taylor P 1997 Mutational analysis of the thyrotropin receptor gene in sporadic and familial feline thyrotoxicosis. Thyroid 7 923-927. (doi:10.1089/thy.1997.7.923)

Peeters ME, Timmermans-Sprang EP \& Mol JA 2002 Feline thyroid adenomas are in part associated with mutations in the $G(s \alpha)$ gene and not with polymorphisms found in the thyrotropin receptor. Thyroid 12 571-575. (doi:10.1089/105072502320288410)

Perrin T 2009 The business of urban animals survey: the facts and statistics on companion animals in Canada. Canadian Veterinary Journal $\mathbf{5 0}$ 48-52.

Peter HJ, Gerber H, Studer H \& Smeds S 1985 Pathogenesis of heterogeneity in human multinodular goiter. A study on growth and function of thyroid tissue transplanted onto nude mice. Journal of Clinical Investigation 76 1992-2002. (doi:10.1172/JCI112199)

Peter HJ, Gerber H, Studer H, Becker DV \& Peterson ME 1987 Autonomy of growth and of iodine metabolism in hyperthyroid feline goiters transplanted onto nude mice. Journal of Clinical Investigation $\mathbf{8 0}$ 491-498. (doi:10.1172/JCI113097)

Peter HJ, Gerber H, Studer H, Peterson ME, Becker DV \& Groscurth P 1991 Autonomous growth and function of cultured thyroid follicles from cats with spontaneous hyperthyroidism. Thyroid 1 331-338. (doi:10.1089/thy.1991.1.331)

Peterson ME 2001 Diagnostic of occult hyperthyroidism. In Consultations in Feline Internal Medicine, 4th edn, pp 145-150. Ed JR August. Philadelphia, PA, USA: W.B. Saunders.

Peterson ME 2012 Hyperthyroidism in cats: what's causing this epidemic of thyroid disease and can we prevent it? Journal of Feline Medicine and Surgery 14 804-818. (doi:10.1177/1098612X12464462)

Peterson ME 2013a Hyperthyroidism in cats. In Clinical Endocrinology of Companion Animals, pp 295-310. Eds JS Rand, E Behrend, D Gunn-Moore \& M Campbell-Ward. Ames, IA, USA: Wiley-Blackwell.

Peterson ME 2013 $b$ More than just T4: diagnostic testing for hyperthyroidism in cats. Journal of Feline Medicine and Surgery 15 765-777. (doi:10.1177/1098612X13500426)

Peterson ME 2013c Feline focus: diagnostic testing for feline thyroid disease: hyperthyroidism. Compendium 35 E1-E6.

Peterson ME 2014 Diagnosis and management of iatrogenic hypothyroidism. In August's Consultations in Feline Internal Medicine. Ed SE Little. Philadelphia, PA, USA: Elsevier [in press].

Peterson ME \& Becker DV 1984 Radionuclide thyroid imaging in 135 cats with hyperthyroidism. Veterinary Radiology \& Ultrasound 25 23-27. (doi:10.1111/j.1740-8261.1984.tb00737.x)

Peterson ME \& Becker DV 1995 Radioiodine treatment of 524 cats with hyperthyroidism. Journal of the American Veterinary Medical Association 207 1422-1428.

Peterson ME, Broome MR \& Rishniw M 2014a The prevalence and degree of thyroid pathology in hyperthyroid cats increase with disease duration: a cross-sectional analysis of 2096 cats referred for radioiodine therapy. Journal of Feline Medicine and Surgery [in press].

Peterson ME \& Broome MR $2014 b$ Thyroid scintigraphy findings in 2,096 cats with hyperthyroidism. Veterinary Radiology \& Ultrasound [in press]. (doi:10.1111/vru.12165)

Peterson ME \& Broome MR 2014c Radioiodine for feline hyperthyroidism. In Kirk's Current Veterinary Therapy XV, pp e112-e122. Eds JD Bonagura \& DC Twedt. Philadelphia, PA, USA: Saunders Elsevier.

Peterson ME, Johnson JG \& Andrews LK 1979 Spontaneous hyperthyroidism in the cat. Proceedings of the American College of Veterinary Internal Medicine 108.

Peterson ME, Kintzer PP, Cavanagh PG, Fox PR, Ferguson DC, Johnson GF \& Becker DV 1983 Feline hyperthyroidism: pretreatment clinical and laboratory evaluation of 131 cases. Journal of the American Veterinary Medical Association 183 103-110.

Peterson ME, Livingston P \& Brown RS 1987 Lack of circulating thyroid stimulating immunoglobulins in cats with hyperthyroidism. Veterinary Immunology and Immunopathology 16 277-282. (doi:10.1016/01652427(87)90024-9)

Peterson ME, Kintzer PP \& Hurvitz AI 1988 Methimazole treatment of 262 cats with hyperthyroidism. Journal of Veterinary Internal Medicine $\mathbf{2}$ 150-157. (doi:10.1111/j.1939-1676.1988.tb02812.x)

Peterson ME, Graves TK \& Gamble DA 1990 Triiodothyronine $\left(\mathrm{T}_{3}\right)$ suppression test. An aid in the diagnosis of mild hyperthyroidism in cats. Journal of Veterinary Internal Medicine 4 233-238. (doi:10.1111/ j.1939-1676.1990.tb03114.x)

Peterson ME, Melian C \& Nichols R 2001 Measurement of serum concentrations of free thyroxine, total thyroxine, and total triiodothyronine in cats with hyperthyroidism and cats with nonthyroidal disease. Journal of the American Veterinary Medical Association 218 529-536. (doi:10.2460/javma.2001.218.529)

Porterfield JR Jr, Thompson GB, Farley DR, Grant CS \& Richards ML 2008 Evidence-based management of toxic multinodular goiter (Plummer's Disease). World Journal of Surgery 32 1278-1284. (doi:10.1007/ s00268-008-9566-0)

Portulano C, Paroder-Belenitsky M \& Carrasco N 2014 The $\mathrm{Na}^{+} / \mathrm{I}^{-}$ symporter (NIS): mechanism and medical impact. Endocrine Reviews $\mathbf{3 5}$ 106-149. (doi:10.1210/er.2012-1036)

Rayalam S, Eizenstat LD, Davis RR, Hoenig M \& Ferguson DC $2006 a$ Expression and purification of feline thyrotropin (fTSH): immunological detection and bioactivity of heterodimeric and yoked glycoproteins. Domestic Animal Endocrinology 30 185-202. (doi:10.1016/j. domaniend.2005.07.004)

Rayalam S, Eizenstat LD, Hoenig M \& Ferguson DC 2006b Cloning and sequencing of feline thyrotropin (fTSH): heterodimeric and yoked constructs. Domestic Animal Endocrinology 30 203-217. (doi:10.1016/ j.domaniend.2005.07.002)

Reese S, Müller M, Kurzke E, Hermanns W \& Kraft W 2002 Prevalence of morphological alterations in feline thyroid glands. Tierärztl Prax Ausg K Kleintiere Heimtiere 30 274-281.

Rios A, Rodriguez JM, Balsalobre MD, Torregrosa NM, Tebar FJ \& Parrilla P 2005 Results of surgery for toxic multinodular goiter. Surgery Today $\mathbf{3 5}$ 901-906. (doi:10.1007/s00595-004-3051-7)

Sarkar SD 2006 Benign thyroid disease: what is the role of nuclear medicine? Seminars in Nuclear Medicine 36 185-193. (doi:10.1053/ j.semnuclmed.2006.03.006)

Sassnau R 2006 Epidemiological investigation of feline hyperthyroidism in a urban population in Germany. Tierärztl Prax Ausg K Kleintiere Heimtiere 34 450-457.

Scarlett JM 1988 Feline hyperthyroidism: a descriptive and case-control study. Preventive Veterinary Medicine 6 295-309. (doi:10.1016/ 0167-5877(88)90041-4)

Schecter A, Malik N, Haffner D, Smith S, Harris TR, Paepke O \& Birnbaum L 2010 Bisphenol A (BPA) in U.S. food. Environmental Science \& Technology 44 9425-9430. (doi:10.1021/es102785d) 
Schott M, Scherbaum WA \& Morgenthaler NG 2005 Thyrotropin receptor autoantibodies in Graves' disease. Trends in Endocrinology and Metabolism 16 243-248. (doi:10.1016/j.tem.2005.05.009)

Selzer E, Wilfing A, Schiferer A, Hermann M, Grubeck-Loebenstein B \& Freissmuth M 1993 Stimulation of human thyroid growth via the inhibitory guanine nucleotide binding $(\mathrm{G})$ protein $\mathrm{Gi}$ : constitutive expression of the G-protein alpha subunit Gi alpha-1 in autonomous adenoma. PNAS 90 1609-1613. (doi:10.1073/pnas.90.4.1609)

Siegel RD \& Lee SL 1998 Toxic nodular goiter. Toxic adenoma and toxic multinodular goiter. Endocrinology and Metabolism Clinics of North America 27 151-168. (doi:10.1016/S0889-8529(05)70304-2)

Siperstein AE, Miller RA, Landis C, Bourne H \& Clark OH 1991 Increased stimulatory $G$ protein in neoplastic human thyroid tissues. Surgery 110 949-955.

Sjollema BE, Pollak YW, van den Brom WE \& Rijnberk A 1989 Thyroidal radioiodine uptake in hyperthyroid cats. Veterinary Quarterly 11 165-170. (doi:10.1080/01652176.1989.9694216)

Sokal JE 1954 Incidence of malignancy in toxic and nontoxic nodular goiter. Journal of the American Medical Association 154 1321-1325. (doi:10.1001/jama.1954.02940500001001)

Sostre S \& Parikh S 1979 A visual index of thyroid function. Clinical Nuclear Medicine 4 59-63. (doi:10.1097/00003072-197902000-00005)

Studer H, Peter HJ \& Gerber H 1989 Natural heterogeneity of thyroid cells: the basis for understanding thyroid function and nodular goiter growth. Endocrine Reviews 10 125-135. (doi:10.1210/edrv-10-2-125)

Suzuki G, Takigami H, Watanabe M, Takahashi S, Nose K, Asari M \& Sakai S 2008 Identification of brominated and chlorinated phenols as potential thyroid-disrupting compounds in indoor dusts. Environmental Science \& Technology 42 1794-1800. (doi:10.1021/es7021895)

Swalec KM \& Birchard SJ 1990 Recurrence of hyperthyroidism after thyroidectomy in cats. Journal of the American Animal Hospital Association 26 433-437.

Syme HM 2007 Cardiovascular and renal manifestations of hyperthyroidism. Veterinary Clinics of North America. Small Animal Practice $\mathbf{3 7}$ 723-743. (doi:10.1016/j.cvsm.2007.05.011)

Szumowski P, Rogowski F, Abdelrazek S, Kociura-Sawicka A \& SokolikOstasz A 2012 Iodine isotope 131-I therapy for toxic nodular goitre: treatment efficacy parameters. Nuclear Medicine Review. Central \& Eastern Europe 15 7-13. (doi:10.5603/NMR.2012.0003)

Thienpont LM, Van Uytfanghe K, Poppe K \& Velkeniers B 2013 Determination of free thyroid hormones. Best Practice \& Research. Clinical Endocrinology \& Metabolism 27 689-700. (doi:10.1016/j.beem. 2013.05.012)

Tonacchera M, Vitti P, Agretti P, Giulianetti B, Mazzi B, Cavaliere R, Ceccarini G, Fiore E, Viacava P, Naccarato A et al. 1998 Activating thyrotropin receptor mutations in histologically heterogeneous hyperfunctioning nodules of multinodular goiter. Thyroid 8 559-564. (doi:10.1089/thy.1998.8.559)

Turrel JM, Feldman EC, Nelson RW \& Cain GR 1988 Thyroid carcinoma causing hyperthyroidism in cats: 14 cases (1981-1986). Journal of the American Veterinary Medical Association 193 359-364.

Uytterspot N, Van Sande J \& Dumont JE 1995 Thyroid adenoma, Gs $\alpha$ expression and the cyclic adenosine monophosphate mitogenic cascade: a complex relationship. Journal of Clinical Endocrinology and Metabolism 80 1518-1520. (doi:10.1210/jcem.80.5.7744995)

Vanderpump MP 2011 The epidemiology of thyroid disease. British Medical Bulletin 99 39-51. (doi:10.1093/bmb/ldr030)

Van de Ven A, Netea-Maier RT, Ross A, van Herwaarden T, Holewijn S, de Graaf J, Kiemeney LA, van Tienoven D, Wetzels JF, Smit JW et al. 2013 Longitudinal trends in thyroid function in relation to iodine intake: ongoing changes of thyroid function despite adequate current iodine status. European Journal of Endocrinology 170 49-54. (doi:10.1530/EJE-13-0589)
Vogt AH, Rodan I, Brown M, Brown S, Buffington CA, Forman MJ, Neilson J \& Sparkes A 2010 AAFP-AAHA: feline life stage guidelines. Journal of the American Animal Hospital Association 46 70-85.

Wahl RL 2013 Thyroid radionuclide uptake and imaging studies. In Werner \& Ingbar's The Thyroid: A Fundamental and Clinical Text, 10th edn, pp 257-278. Eds LE Braverman \& DS Cooper. Philadelphia, PA, USA: Lippincott Williams \& Wilkins.

Wakeling J, Smith K, Scase T, Kirkby R, Elliott J \& Syme H 2007 Subclinical hyperthyroidism in cats: a spontaneous model of subclinical toxic nodular goiter in humans? Thyroid 17 1201-1209. (doi:10.1089/thy. 2007.0225)

Wakeling J, Everard A, Brodbelt D, Elliott J \& Syme H 2009 Risk factors for feline hyperthyroidism in the UK. Journal of Small Animal Practice $\mathbf{5 0}$ 406-414. (doi:10.1111/j.1748-5827.2009.00756.x)

Wakeling J, Elliott J \& Syme H 2011 Evaluation of predictors for the diagnosis of hyperthyroidism in cats. Journal of Veterinary Internal Medicine 25 1057-1065. (doi:10.1111/j.1939-1676.2011.00790.x)

Ward CR, Achenbach SE, Holt D, Peterson ME \& Meinkoth JL $2005 a$ Thyrotropin-stimulated DNA synthesis and thyroglobulin expression in normal and hyperthyroid feline thyrocytes in monolayer culture. Thyroid 15 114-120. (doi:10.1089/thy.2005.15.114)

Ward CR, Achenbach SE, Peterson ME, Drobatz KJ \& Holt D $2005 b$ Expression of inhibitory $\mathrm{G}$ proteins in adenomatous thyroid glands obtained from hyperthyroid cats. American Journal of Veterinary Research 66 1478-1482. (doi:10.2460/ajvr.2005.66.1478)

Ward CR, Windham WR \& Dise D 2010 Evaluation of activation of $\mathrm{G}$ proteins in response to thyroid stimulating hormone in thyroid gland cells from euthyroid and hyperthyroid cats. American Journal of Veterinary Research 71 643-648. (doi:10.2460/ajvr.71.6.643)

Waters DJ 1993 Endocrine system. In Atlas of Feline Anatomy for Veterinarians, pp 127-134. Eds LC Hudson \& WP Hamilton. Philadelphia, PA, USA: W.B. Saunders.

Watson SG, Radford AD, Kipar A, Ibarrola P \& Blackwood L 2005 Somatic mutations of the thyroid-stimulating hormone receptor gene in feline hyperthyroidism: parallels with human hyperthyroidism. Journal of Endocrinology 186 523-537. (doi:10.1677/joe.1.06277)

Welches CD, Scavelli TD, Matthiesen DT \& Peterson ME 1989 Occurrence of problems after three techniques of bilateral thyroidectomy in cats. Veterinary Surgery 18 392-396. (doi:10.1111/j.1532-950X.1989. tb01107.x)

Wells AL, Long CD, Hornof WJ, Goldstein RE, Nyland TG, Nelson RW \& Feldman EC 2001 Use of percutaneous ethanol injection for treatment of bilateral hyperplastic thyroid nodules in cats. Journal of the American Veterinary Medical Association 218 1293-1297. (doi:10.2460/javma. 2001.218.1293)

Wettschureck N \& Offermanns S 2005 Mammalian G proteins and their cell type specific functions. Physiological Reviews 85 1159-1204. (doi:10.1152/physrev.00003.2005)

Williams TL, Elliott J \& Syme HM 2010 Association of iatrogenic hypothyroidism with azotemia and reduced survival time in cats treated for hyperthyroidism. Journal of Veterinary Internal Medicine $\mathbf{2 4}$ 1086-1092. (doi:10.1111/j.1939-1676.2010.0566.x)

Wisner ER 1994 Ultrasonographic examination of the thyroid gland of hyperthyroid cats: comparison to ${ }^{99} \mathrm{TcO}_{4}$ scintigraphy. Veterinary Radiology \& Ultrasound 35 53-58. (doi:10.1111/j.1740-8261.1994. tb00178.x)

Zakarija M \& McKenzie JM 1990 Do thyroid growth-promoting immunoglobulins exist? Journal of Clinical Endocrinology and Metabolism 70 308-310. (doi:10.1210/jcem-70-5-1239)

Zoeller TR 2010 Environmental chemicals targeting thyroid. Hormones $\mathbf{9}$ 28-40. (doi:10.14310/horm.2002.1250)

Received in final form 17 August 2014

Accepted 20 August 2014 http://joe.endocrinology-journals.org DOI: 10.1530/JOE-14-0461
() 2014 Society for Endocrinology Printed in Great Britain
Published by Bioscientifica Ltd 